\title{
Late Glacial and Holocene buried black soils in Emilia (northern Italy): genetic and paleoenvironmental insights
}

\author{
G. Bianchini ${ }^{1}$. C. A. Accorsi ${ }^{2}$. S. Cremonini ${ }^{3}$ - M. De Feudis ${ }^{4}$ L. Forlani ${ }^{2}$. G. M. Salani ${ }^{1}$ - G. Vianello ${ }^{4}$. \\ L. Vittori Antisari ${ }^{4}$
}

Received: 25 January 2021 / Accepted: 5 October 2021 / Published online: 26 October 2021

(c) The Author(s) 2021

\begin{abstract}
Purpose The existence of black horizons (BHs) is often highlighted in European soils, and in the Po River plain of northern Italy. Nevertheless, BH chronological frameworks and genetic models are still debated. The present study investigated the genesis of BHs in the eastern Po Plain where they are buried at various depths.

Materials and methods Soil sequences were investigated with a multidisciplinary approach integrating geomorphologic, stratigraphic, pedologic, geochemical, isotopic, palynological, and radiometric analyses.

Results and discussion The formation of the studied BHs was scattered over time from the Last Glacial Maximum to at least the middle Holocene. The new data indicate that BHs developed when the landscape was dominated by coniferous forest during conditions that were totally different from the current pedoclimatic setting. The recurrent presence of black particles indicates that this vegetation cover was systematically affected by fire episodes that induced soil degradation and mineralization processes of the original organic compounds, thus contributing to darkening of the upper soil horizons.

Conclusions BH formation clearly coincided with cold time lapses. Evidence for repeated fire events (natural or humaninduced?) provides insights for the controversial debate on early anthropogenic impacts on the environment.
\end{abstract}

Keywords Buried black soils $\cdot$ Late Glacial and Holocene $\cdot$ Geochemistry $\cdot$ Palynology $\cdot$ Black particles $\cdot$ Radiocarbon dating

\section{Highlights}

- Buried soils in Emilia (Italy) include peculiar black horizons.

- Black horizon geochemistry highlights carbonate depletion and high metal concentrations.

- Palynology reveals cold/cool climatic conditions during black horizon genesis.

- Radiocarbon dating constrains black horizon formation during cold/cool periods.

- The presence of black particles indicates repeated natural or human-induced fire episodes.

Responsible editor: Heike Knicker

G. Bianchini

bncglc@unife.it

1 Dipartimento Di Fisica E Scienze Della Terra, Università Di Ferrara, Ferrara, Italy

2 Studio "La Torretta", Bologna, Italia

3 Dipartimento Di Scienze Biologiche, Geologiche E Ambientali, Università Di Bologna, Bologna, Italy

4 Dipartimento Di Scienze E Tecnologie Agro-Alimentari, Università Di Bologna, Bologna, Italy

\section{Introduction}

Pedogenetic processes and the resulting soil types are strictly dependent on existing climatic conditions (Schaetzl and Anderson 2005; Clark et al. 2012; Walker et al. 2012; Meier et al. 2014; Mauri et al. 2015; Tabor and Myers 2015; Binney et al. 2017; Pérez-Lambán et al. 2017; Zhou et al. 2021). The prominent role played by climate change over time, particularly between the end of the Pleistocene and the early Holocene, in conditioning soil-forming processes through vegetation cover change has been observed in various case studies (Tallón-Armada et al. 2014; Malkiewicz et al. 2016; Pérez-Lambán et al. 2017; Chendev et al. 2018; Armas-Herrera et al. 2019). In northern Italy, the majority of the sites studied from a paleoenvironmental perspective are hilly and mountain settings, mainly lacustrine environments characterized by continuity of sedimentation (e.g., Vescovi et al. 2010; Joannin et al. 2013, and references 
therein). On the other hand, case studies performed in wide alluvial plains with high discontinuous sedimentation rates are rare (Ravazzi et al. 2006; Marchesini et al. 2017; Bruno et al. 2020; Marcolla et al. 2021). In this framework, during recent decades, excavation for building and engineering activities in the eastern Po Plain (northern Italy) targeted stratigraphic sequences that were well constrained from archeological and chronological points of view (Bianchini et al. 2014, 2019; Cacciari et al. 2017; Vittori Antisari et al. 2011, 2013a). In these pilot studies, buried soils dating back to the early Holocene and up to the late Middle Ages, i.e., the regional Holocene pedocomplex, were recognized (Fig. 1). The significant thickness of the sedimentary cover is effective in sealing and preserving the main soil features. These sequences often contain black soils, which, although already described by previous studies in the Po Plain (e.g., Amorosi et al. 2014a, 2017; Bruno et al. 2020; Marcolla et al. 2021), have not been interpreted in terms of paleoenvironmental conditions. Notably, in other European countries (e.g., Spain), black soils have been ascribed to specific climatic conditions, vegetation types, and the occurrence of fires (Tallón-Armada et al. 2014; Armas-Herrera et al. 2019), and related hypotheses need to be tested in northern Italy.

In this paper, we investigated three stratigraphic successions that contain black soil horizons by integrating new pedological, geochemical, chronological, palynological, and black particle data. The results were compared with similar investigations recently carried out in surrounding areas (Vittori Antisari et al. 2016, and references therein) to provide new insights into the ecological and physiographic evolution of the area and to highlight the specific genetic conditions of black soils.

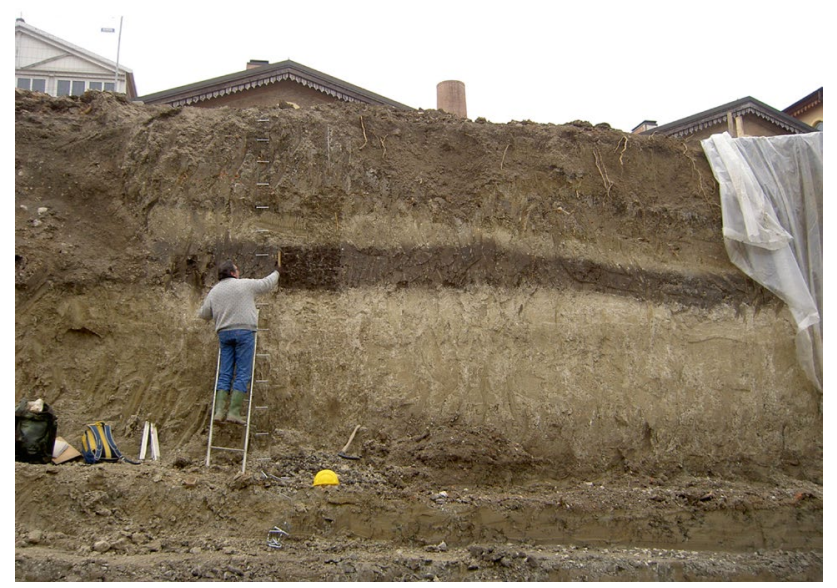

Fig. 1 Typical example of a buried black soil in the areas surrounding Bologna. In particular, the picture refers to the studied site of Salara (site 3-SAL)

\section{Regional settings}

\subsection{Location and present-day climate}

The studied sites (and those used for comparison) are located in Bologna City and in its periphery (Fig. 2). The present-day climate of this area is characterized by the following mean annual (1960-2008) parameters: air temperature ranging between 13 and $14{ }^{\circ} \mathrm{C}, 700-1000 \mathrm{~mm} /$ year of rainfall, $800-900 \mathrm{~mm}$ of potential evapotranspiration, $0.65-1.00$ of the FAO-UNEP aridity index (subhumid type), xeric soil moisture regime (80-115 day/year), and mesic soil temperature regime (Costantini et al. 2013).

In this area, affected by a very severe human influence, the natural vegetation is pedunculate oak and common hornbeam. The latter wood, characterized by Quercus robur, Carpinus betulus, and Acer campestre, represents the potential vegetation, today almost completely destroyed. Moreover, there is riparian vegetation with remnants of riparian natural woods (Salix alba, Salix purpurea, Populus nigra and more rarely Alnus glutinosa, and Ulmus minor; Puppi et al. 2010).

\subsection{Geology and geomorphology}

The three studied sites (Fig. 2) are located in the middle of the Reno River mountain valley (site 1) and close to the Apennine chain foothills at the apex and lower margin, respectively, of the minor Aposa stream alluvial fan (sites 2 and 3 ).

The Apennine is a very young and still active mountain belt bordering the southern margin of the Po River sedimentary basin (Fantoni and Franciosi 2010), whose topographic evolution mainly developed after the Messinian (Ghielmi et al. 2010, 2012), during the late Pliocene and Pleistocene (Martelli et al. 2017a, b), inducing a generalized uplift of the chain (Muttoni et al. 2003; Gunderson et al. 2014). These processes generated the Pedeapenninic Thrust Front (Boccaletti et al. 1985) lying beneath the city of Bologna and currently uplifting at a rate of ca. $1 \mathrm{~mm} /$ year (D'Anastasio et al. 2006; Carminati and Vadacca 2010), while the alluvial plain is subsiding at a rate of $0.5-2 \mathrm{~mm} /$ year (Carminati and Martinelli 2002).

Site 1-MRZ (Marzabotto), lying in the core of the mountain chain, approximately $30 \mathrm{~km}$ upstream of the valley termination, contains an alluvial terrace system carved in a Tertiary marly formation (Marne di Cigarello $\mathrm{Fm}$ ) (Fig. 2A), which was generated by the Reno River during the middle to upper Pleistocene. Terrace Ft2 was still flooded during the nineteenth and twentieth 

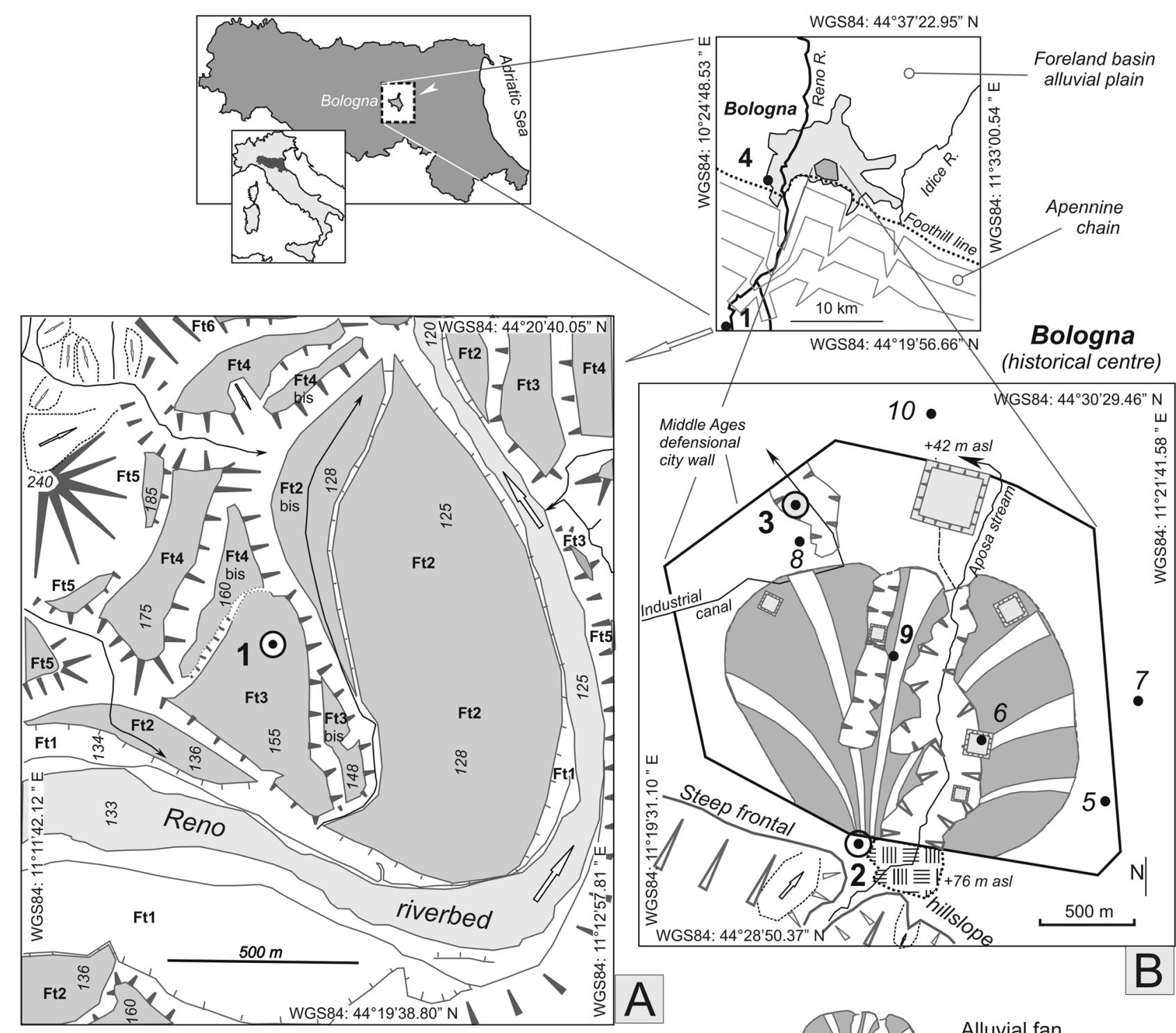

Bologna

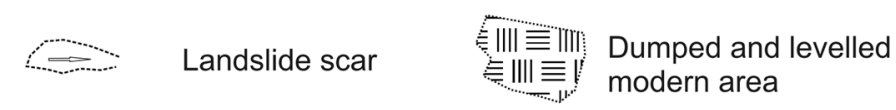

TIT Terrace footslope modern area

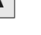

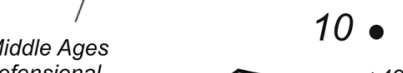

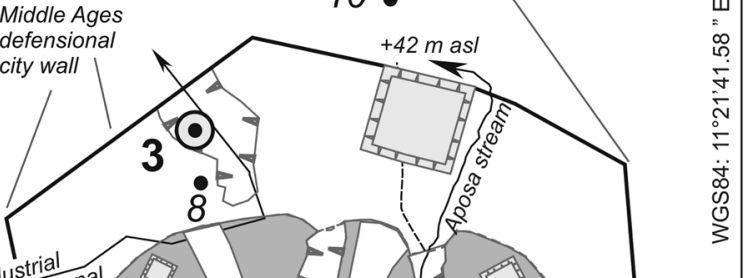

Ft 4 Fluvial terrace order

$$
\begin{aligned}
& \text { Main artificial } \\
& \text { geomorphological unit }
\end{aligned}
$$

Ft 1 Flood (active) terrace

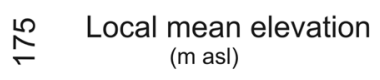

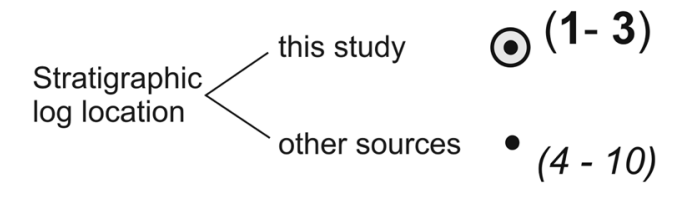

Fig. 2 Geographic location and physical settings of the studied sites (1-3) and those taken for comparison (4-10). A Geomorphologic map of site 1-MRZ. B Essential geomorphologic elements of the

centuries AD. Terrace Ft3, hosting the studied stratigraphic succession of site 1 , lies approximately $25 \mathrm{~m}$ above the present river talweg and dates back to approximately 19 ky BP (Picotti and Pazzaglia 2008). The Ft3
Bologna city center and location of stratigraphic sites 2 and 3. Sites 4 to 10 (see Supplementary Table 5) are recalled in the discussion

terrace hosts the Etruscan Age town structures of Kainua (sixth to fourth centuries BC: Bertani 2010) and was settled by at least the Chalcolithic and the Bronze Age (Cattani and Govi 2010). 
Site 2-SMA (Bologna, S. Mamolo) lies at the valley end of the Aposa small stream (Cremonini 2002) at the transition of its apical fan area (Fig. 2B). The Aposa alluvial fan coincides with the Bologna historical settlement starting from the eighth century BC (Malnati 2010). Such a long-lasting period of settlement generated a 2-4-m-thick anthropogenic deposit prism (Giorgi 2002) and makes recognition of the pristine, natural fan morphology difficult (Cremonini 1991). The most prominent morphologies in the fan area are those of two stream trenches (Fig. 2B) corresponding to the active Aposa stream course (Cremonini and Bracci 2010) and a second artificial course lying near site 3 . On the southern side of the medieval town, near site 2 , a thick series of leveling deposits masks the morphological transition between the Aposa valley termination and the subsequent fan trench.

Site 3-SAL (Bologna, Salara) lies near the lower boundary of the Aposa stream alluvial fan, where the overbank silty deposits prevail with respect to the channel sandygravelly facies (Amorosi et al. 2014b).

\section{Methods and materials}

\subsection{Field survey and sampling}

The three investigated sites $(1-\mathrm{MRZ}=$ Marzabotto; 2-SMA = Bologna-San Mamolo; 3-SAL = BolognaSalara) were selected in correspondence with engineering excavations and were studied from stratigraphic and pedological points of view (Table 1; Fig. 3). The field observations allowed the recognition of stratigraphic units identified on the basis of distinctive characteristics (layer geometry and lateral relationships, mineral groundmass, coarse-grain-sized natural elements, colors, physical stress surfaces, postdepositional disturbances, human artifacts, and related ages). The morphological characteristics of each soil horizon were described according to Schoeneberger et al. (2012). Each soil horizon was sampled by collecting approximately $1 \mathrm{~kg}$ of material for analytical investigation.

Table 1 Soils morphological and physicochemical characters of the site 1 (MRZ), site 2 (SMA), and site 3 (SAL) stratigraphic successions. Black horizons are highlighted by gray background

\begin{tabular}{|c|c|c|c|c|c|c|c|c|c|c|c|}
\hline \multirow{2}{*}{\multicolumn{2}{|c|}{ Soil profile }} & \multirow[b]{2}{*}{ Horizon } & \multirow{2}{*}{$\begin{array}{c}\text { Depth } \\
\text { cm } \\
\end{array}$} & \multirow{2}{*}{\multicolumn{2}{|c|}{$\begin{array}{c}\text { Color (dry) } \\
\text { Munsell's Chart }\end{array}$}} & \multirow{2}{*}{$\begin{array}{c}\mathrm{pH} \\
\left(\mathrm{H}_{2} \mathrm{O}\right) \\
\end{array}$} & \multirow{2}{*}{$\begin{array}{c}\mathrm{CaCO}_{3} \\
\text { total }\end{array}$} & \multicolumn{3}{|c|}{ Texture } & \multirow{2}{*}{$\begin{array}{c}\text { Accumulation of } \\
\text { materials } \\
\text { (Concentrations, } \\
\text { fragments, artifacts) * }\end{array}$} \\
\hline & & & & & & & & Sand & Silt & Clay & \\
\hline \multirow{5}{*}{$\begin{array}{l}\text { Site } 1 \\
\text { MRZ }\end{array}$} & \multirow[b]{2}{*}{1} & $\overline{A p}$ & $0-40$ & Dark grayish brown & $10 \mathrm{YR} 4 / 2$ & 8.5 & 666 & 116 & 691 & 193 & \\
\hline & & $\mathrm{AC}$ & $40-75$ & Gray & $2.5 \mathrm{Y} 6 / 1$ & 8.7 & 113 & 46 & 752 & 202 & \\
\hline & \multirow{2}{*}{2} & A1 & $75-100$ & Grayish brown & $2.5 Y 5 / 2$ & 8.6 & 142 & 52 & 683 & 265 & \\
\hline & & $\mathbf{A 2}$ & $100-155$ & Dark grayish brown & $2.5 \mathrm{Y} 4 / 2$ & 8.6 & 64.4 & 96 & 690 & 214 & \\
\hline & 3 & 3AC & $180-200+$ & Grayish brown & 10YR $5 / 2$ & 8.5 & 103 & 302 & 522 & 176 & \\
\hline \multirow{15}{*}{$\begin{array}{l}\text { Site } 2 \\
\text { SMA }\end{array}$} & \multirow{2}{*}{1} & Ap & $0-22$ & Light olive gray & $5 \mathrm{Y} 6 / 2$ & 8.5 & 132 & 268 & 548 & 184 & \\
\hline & & Apu & $22-74$ & Dark graysh brown & $2.5 \mathrm{Y} 4 / 2$ & 8.3 & 122 & 407 & 499 & 94 & AB-AP \\
\hline & \multirow{2}{*}{2} & Apu & $74-106$ & Light olive brown & $2.5 \mathrm{Y} 5 / 4$ & 8.6 & 172 & 312 & 501 & 187 & $\mathrm{AB}$ \\
\hline & & CA & 106-135 & Pale brown & $2.5 Y 7 / 4$ & 8.5 & 135 & 303 & 504 & 193 & \\
\hline & \multirow{3}{*}{3} & $\mathbf{A}$ & $135-179$ & Olive brown & $2.5 \mathrm{Y} 4 / 4$ & 8.3 & 15.5 & 154 & 652 & 194 & \\
\hline & & $\mathbf{A C}$ & $179-202$ & Olive brown & $2.5 \mathrm{Y} 4 / 4$ & 8.7 & 191 & 184 & 629 & 187 & CAC - SFB \\
\hline & & $\mathbf{C k}$ & 202-227 & Light olive brown & $2.5 Y 5 / 4$ & 8.6 & 335 & 179 & 635 & 186 & $\mathrm{CAC}$ \\
\hline & \multirow{2}{*}{4} & $\mathbf{A}$ & $227-250$ & Light olive brown & $2.5 Y 5 / 4$ & 8.7 & 360 & 194 & 633 & 173 & \\
\hline & & AC & $250-262$ & Light yellowish brown & $2.5 \mathrm{Y} 6 / 4$ & 8.8 & 380 & 195 & 629 & 176 & SFB \\
\hline & \multirow{2}{*}{5} & $\mathbf{A}$ & $262-282$ & Olive brown & $2.5 \mathrm{Y} 4 / 4$ & 8.7 & 386 & 199 & 618 & 183 & \\
\hline & & C & $282-313$ & Light yellowish brown & $2.5 \mathrm{Y} 6 / 4$ & 8.8 & 337 & 188 & 557 & 255 & $\mathrm{CAC}$ \\
\hline & \multirow{4}{*}{6} & A1 & $313-330$ & Very dark gray & $2,5 Y 3 / 1$ & 8.2 & 28.9 & 93 & 689 & 218 & \\
\hline & & $\mathbf{A 2}$ & 330-342 & Very dark grayish brown & $2.5 \mathrm{Y} 3 / 2$ & 8.2 & 28.9 & 112 & 705 & 183 & \\
\hline & & AC & $342-362$ & Dark olive brown & $2.5 \mathrm{Y} 3 / 3$ & 8.4 & 24.4 & 97 & 694 & 209 & \\
\hline & & $\mathbf{C k}$ & $362-380$ & Light olive brown & $2.5 Y 5 / 3$ & 8.6 & 300 & 199 & 613 & 188 & $\mathrm{CAC}$ \\
\hline \multirow{14}{*}{$\begin{array}{l}\text { Site } 3 \\
\text { SAL }\end{array}$} & \multirow{2}{*}{1} & AC1 & $330-340$ & Light brownish gray & $2.5 \mathrm{Y} 6 / 2$ & 8.0 & 127 & 153 & 663 & 184 & SFB \\
\hline & & AC2 & $340-360$ & Light yellowish brown & $2.5 \mathrm{Y} 6 / 3$ & 8.0 & 155 & 122 & 697 & 181 & SFB \\
\hline & \multirow{2}{*}{2} & AC1 & $360-370$ & Light olive brown & $2.5 Y 5 / 3$ & 8.2 & 122 & 42 & 770 & 188 & SFB \\
\hline & & $\mathrm{AC2}$ & $370-405$ & Light gray & $2.5 \mathrm{Y} 7 / 2$ & 8.0 & 184 & 35 & 736 & 229 & SFB \\
\hline & \multirow{4}{*}{3} & A1 & $405-427$ & Dark grayish brown & $2.5 \mathrm{Y} 4 / 2$ & 8.1 & 50.2 & 63 & 727 & 210 & \\
\hline & & $\mathbf{A 2}$ & $427-460$ & Grayish brown & $2.5 \mathrm{Y} 5 / 2$ & 7.9 & 48,8 & 77 & 690 & 233 & \\
\hline & & BCk & $460-470$ & Pale yellow & $2.5 Y 7 / 3$ & 8.1 & 344 & 70 & 762 & 168 & $\mathrm{CAC}$ \\
\hline & & Ckk & $470-505$ & Pale yellow & $2.5 \mathrm{Y} 8 / 2$ & 8.1 & 431 & 74 & 756 & 170 & $\mathrm{CAC}$ \\
\hline & \multirow{3}{*}{4} & $\mathbf{A C}$ & $505-525$ & Light gray & $2.5 \mathrm{Y} 7 / 2$ & 8.3 & 226 & 46 & 761 & 193 & $\mathrm{CH}$ \\
\hline & & C & 525-585 & Light gray & $2.5 \mathrm{Y} 7 / 1$ & 8.3 & 255 & 27 & 742 & 231 & FMC \\
\hline & & $\mathbf{C k}$ & $585-610$ & Light gray & $2.5 \mathrm{Y} 7 / 2$ & 8.3 & 322 & 25 & 778 & 197 & CAC- FMC \\
\hline & \multirow{2}{*}{5} & AC & $610-680$ & Pale yellow & $2.5 \mathrm{Y} 7 / 3$ & 8.1 & 253 & 44 & 764 & 192 & FMC - SFB \\
\hline & & C & $680-738$ & Light gray & $2.5 \mathrm{Y} 7 / 1$ & 8.1 & 180 & 19 & 734 & 247 & CAC - FMC \\
\hline & 6 & $\mathbf{A}$ & $738-800$ & Gray & $2.5 \mathrm{Y} 6 / 1$ & 8.0 & 59.9 & 18 & 713 & 269 & \\
\hline
\end{tabular}

$\mathbf{M R Z}=$ Marzabotto - SMA $=$ San Mamolo $(\mathrm{BO})-\mathbf{S A L}=$ Salara $(\mathrm{BO})-\mathbf{C A C}=$ carbonate concretions or nodules $-\mathbf{F M C}=$ iron-manganese concretions $-\mathbf{S F B}=$ shell fragments $-\mathbf{A B}=$ bricks $-\mathbf{A P}=$ pottery $-\mathbf{C H}=$ charcoal 


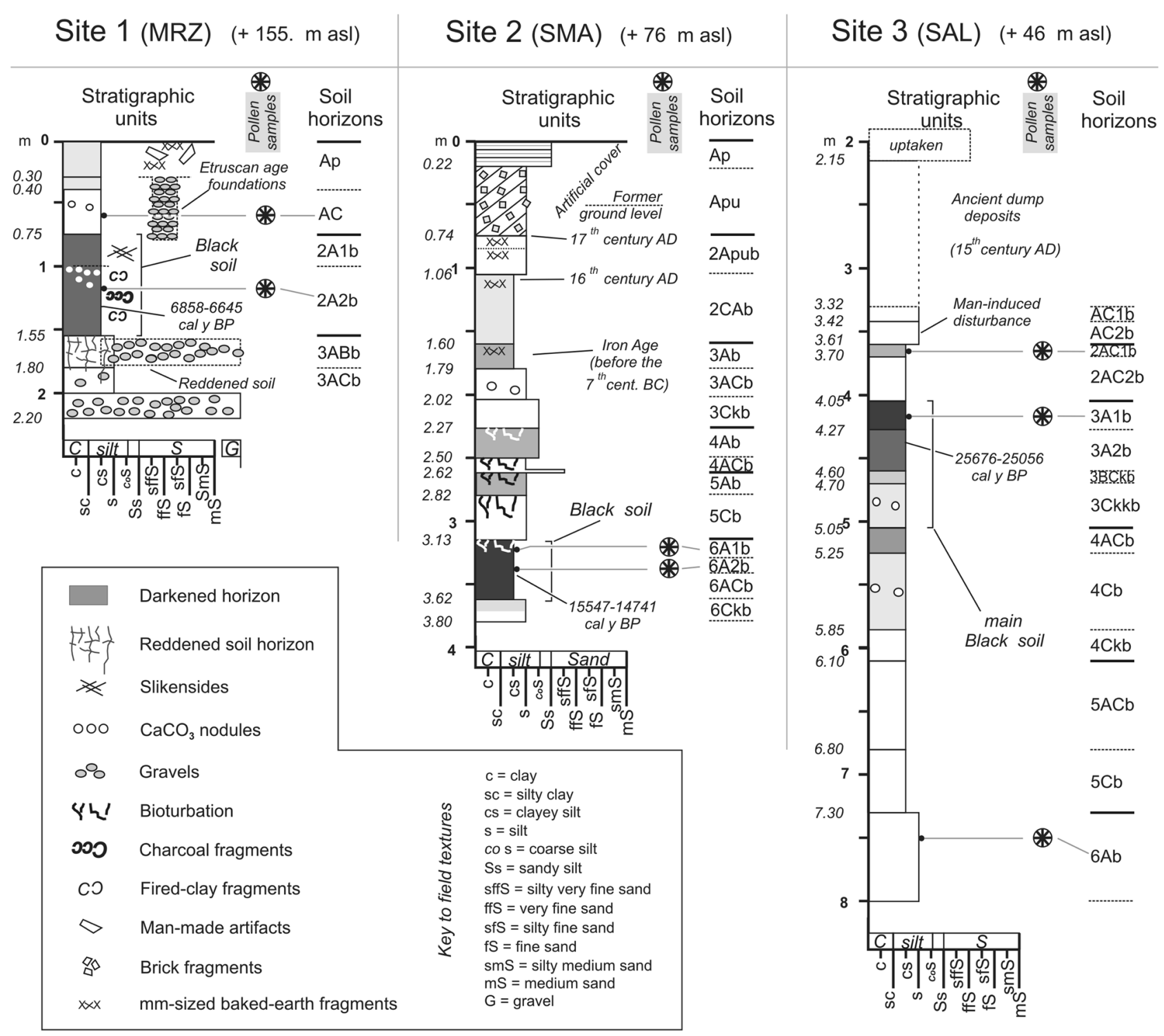

Fig. 3 Stratigraphic logs and related succession of buried soil profiles recorded at the three studied sites (1-3). Radiometric datings are expressed at the $2 \sigma$ interval

\subsection{Analytical methods}

\subsubsection{Grain size and physicochemical analyses}

Soil samples were air dried and dry-sieved with a 2-mm mesh sieve. The particle size distribution was determined by the pipette method after dispersion of the sample with a sodium hexametaphosphate solution (Gee and Brauder 1986). The $\mathrm{pH}$ was determined potentiometrically in a 1:2.5 (w/v) soil:distilled water suspension with a Crison $\mathrm{pH}$ meter. The carbonate content was measured by volumetric analysis of the carbon dioxide released by a $6 \mathrm{M} \mathrm{HCl}$ solution (Loeppert and Suarez 1996).

\subsubsection{Carbon speciation and isotopic analysis}

Soil samples were finely powdered using an automated agate mortar. Carbon speciation was carried out with an innovative method recently defined as "smart combustion" (Zethof et al. 2019) using an Elementar SoliTOC analyzer, which allows oxidation-temperature-dependent differentiation of distinct carbon fractions. The analytical run takes $1600 \mathrm{~s}$ and involves a three-step heating of the samples at $400{ }^{\circ} \mathrm{C}$, $600{ }^{\circ} \mathrm{C}$, and $900{ }^{\circ} \mathrm{C}$ coupled with holding times of 230 , 120 , and $150 \mathrm{~s}$, respectively. The formed $\mathrm{CO}_{2}$ was detected by an infrared detector. Accuracy and precision, evaluated by repeated analyses of samples and of soil standards, 
Table 2 Contents of carbonates (CaCO3), total carbon (TC), total organic carbon (TOC), total inorganic carbon (TIC), $\delta^{13} \mathrm{C}$ of $\mathrm{TC}$, TOC, and TIC in black horizons (BH) and in non-black horizons of the site 1 (MRZ), site 2 (SMA), and site 3 (SAL) stratigraphic successions. * indicates significant differences between black and non-black horizons within each site according to Kruskal-Wallis test $(P<0.05)$

\begin{tabular}{|c|c|c|c|c|c|c|c|}
\hline Site & $\mathrm{CaCO}_{3}$ & $\mathrm{TC}$ & TOC & TIC & $\delta^{13} \mathrm{C}_{\mathrm{TC}}$ & $\delta^{13} \mathrm{C}_{\mathrm{TOC}}$ & $\delta^{13} \mathrm{C}_{\mathrm{TIC}}$ \\
\hline & $\%$ & & & & $\% 0$ & & \\
\hline MRZ & 9.7 & 2.09 & 0.86 & 1.23 & -12.90 & -23.66 & -6.80 \\
\hline MRZ-BH & 10.3 & 2.11 & 0.91 & 1.19 & -13.98 & -23.63 & -8.10 \\
\hline SMA & 24.0 & 3.74 & 0.55 & 3.19 & -6.98 & -21.58 & -4.70 \\
\hline \multirow[t]{2}{*}{ SMA-BH } & 2.44 & 1.21 & 0.82 & 0.39 & -17.88 & -23.98 & -9.95 \\
\hline & $*$ & $*$ & & $*$ & $*$ & & $*$ \\
\hline SAL & 23.6 & 3.68 & 0.52 & 3.16 & -6.70 & -21.81 & -4.02 \\
\hline \multirow[t]{2}{*}{ SAL-BH } & 5.3 & 1.15 & 0.50 & 0.65 & -14.69 & -22.98 & -9.15 \\
\hline & $*$ & $*$ & & $*$ & $*$ & & $*$ \\
\hline
\end{tabular}

were better than $5 \%$ of the measured concentration (Natali et al. 2020). Carbon isotopic analysis of the TC, TOC, and TIC was carried out with an elemental analyzer variomicrocube coupled with an isotope ratio mass spectrometer (IRMS) Isoprime 100, according to the protocol defined by Natali and Bianchini (2015) and Natali et al. (2018). Data are reported in Supplementary Table 1 and summarized in Table 2.

\subsubsection{Geochemical analyses by XRF and ICP-OES}

$\mathrm{X}$-ray fluorescence (XRF) analysis was carried out for the measurement of major elements according to the following procedure. Approximately $4 \mathrm{~g}$ of powder was pressed with the addition of boric acid by a hydraulic press to obtain powder pellets. Simultaneously, 0.5-0.6 g of powder was heated for approximately $12 \mathrm{~h}$ in a furnace at $1000{ }^{\circ} \mathrm{C}$ to determine the LOI (loss on ignition) values. This parameter measures the concentration of volatile species (e.g., $\mathrm{H}_{2} \mathrm{O}, \mathrm{CO}_{2}$, and halogens) contained in the sample. The analysis of the powder pellets was carried out using an ARL Advant-XP spectrometer, which was properly calibrated analyzing certified reference materials, as described by Di Giuseppe et al. (2014). Precision and accuracy were calculated by repeated analysis of international standards having matrices comparable with those investigated, i.e., various typologies of sedimentary rocks, and were generally better than $3 \%$ for $\mathrm{Si}, \mathrm{Ti}$, $\mathrm{Fe}, \mathrm{Ca}$, and $\mathrm{K}$, and $7 \%$ for $\mathrm{Mg}, \mathrm{Al}, \mathrm{Mn}$, and $\mathrm{Na}$. Data are reported in Supplementary Table 2 and summarized in Table 3.

Inductively coupled plasma optical emission spectrometry (ICP-OES) on aqua regia leachates was carried out for trace element analysis according to the following procedure. Approximately $0.25 \mathrm{~g}$ of dried soil was treated with aqua regia $(6 \mathrm{~mL} 37 \% \mathrm{HCl}$ and $3 \mathrm{~mL} 65 \%$ $\mathrm{HNO}_{3}$ Suprapur, E. Merck, Germany), following the procedure proposed by Vittori Antisari et al. (2013b); mineralization was carried out in Teflon bombs in a Milestone 1200 microwave oven and element concentrations were determined using a Spectro Arcos Ametek spectrometer. The accuracy of the instrumental method and analytical procedures was checked by repeating (three times) the analysis of samples and international reference materials (BCR) and laboratory internal standards, as described by Vittori Antisari et al. (2014). Data are reported in Supplementary Table 3 and summarized in Table 4.
Table 3 Contents of $\mathrm{SiO}_{2}, \mathrm{TiO}_{2}$, $\mathrm{Al}_{2} \mathrm{O}_{3}, \mathrm{Fe}_{2} \mathrm{O}_{3}, \mathrm{CaO}, \mathrm{K}_{2} \mathrm{O}, \mathrm{MgO}$, $\mathrm{MnO}, \mathrm{Na}_{2} \mathrm{O}$, and $\mathrm{P}_{2} \mathrm{O}_{5}$ in black horizons $(\mathrm{BH})$ and in non-black horizons of the site 1 (MRZ), site 2 (SMA), and site 3 (SAL) stratigraphic successions. * indicates significant differences between black and non-black horizons within each site according to Kruskal-Wallis test $(P<0.05)$

\begin{tabular}{lllllllllll}
\hline Site & $\mathrm{SiO}_{2}$ & $\mathrm{TiO}_{2}$ & $\mathrm{Al}_{2} \mathrm{O}_{3}$ & $\mathrm{Fe}_{2} \mathrm{O}_{3}$ & $\mathrm{CaO}$ & $\mathrm{K}_{2} \mathrm{O}$ & $\mathrm{MgO}$ & $\mathrm{MnO}$ & $\mathrm{Na}_{2} \mathrm{O}$ & $\mathrm{P}_{2} \mathrm{O}_{5}$ \\
\hline$\%$ & & & & & & & & & & \\
MRZ & 56.9 & 0.62 & 13.9 & 5.35 & 6.61 & 2.15 & 2.60 & 0.18 & 0.63 & 0.14 \\
MRZ-BH & 53.4 & 0.67 & 15.3 & 5.69 & 6.12 & 2.36 & 2.94 & 0.10 & 0.45 & 0.06 \\
& & & $*$ & & & $*$ & $*$ & & $*$ & \\
SMA & 47.5 & 0.49 & 10.5 & 3.58 & 16.41 & 1.90 & 2.26 & 0.09 & 0.83 & 0.36 \\
SMA-BH & 61.1 & 0.69 & 15.0 & 5.12 & 3.05 & 2.73 & 2.90 & 0.10 & 0.80 & 0.16 \\
& $*$ & $*$ & $*$ & $*$ & $*$ & $*$ & $*$ & & & \\
SAL & 45.1 & 0.53 & 11.3 & 4.18 & 15.90 & 1.87 & 2.71 & 0.07 & 0.62 & 0.14 \\
SAL-BH & 57.1 & 0.72 & 15.7 & 5.59 & 4.32 & 2.38 & 2.93 & 0.10 & 0.67 & 0.09 \\
& $*$ & $*$ & $*$ & $*$ & $*$ & $*$ & & & & \\
\hline
\end{tabular}


Table 4 Contents of As, B, Be, Cd, Co, Cr, Cu, Li, Mo, Ni, Pb, Sb, $\mathrm{Sn}, \mathrm{Sr}, \mathrm{V}$, and $\mathrm{Zn}$ in black horizons $(\mathrm{BH})$ and in non-black horizons of the site 1 (MRZ), site 2 (SMA), and site 3 (SAL) stratigraphic suc-

\begin{tabular}{|c|c|c|c|c|c|c|c|c|c|c|c|c|c|c|c|c|}
\hline Site & As & B & $\mathrm{Be}$ & $\mathrm{Cd}$ & $\mathrm{Co}$ & $\mathrm{Cr}$ & $\mathrm{Cu}$ & $\mathrm{Li}$ & Mo & $\mathrm{Ni}$ & $\mathrm{Pb}$ & $\mathrm{Sb}$ & $\mathrm{Sn}$ & $\mathrm{Sr}$ & $\mathrm{V}$ & $\mathrm{Zn}$ \\
\hline & \multicolumn{16}{|c|}{$\mathrm{mg} \mathrm{kg}^{-1}$} \\
\hline MRZ & 3.79 & 42.1 & 1.25 & 0.25 & 12.1 & 84.0 & 31.1 & 53.2 & 1.00 & 54.2 & 24.2 & 1.27 & 2.20 & 127 & 63.0 & 88.0 \\
\hline MRZ-BH & 3.36 & $\begin{array}{l}66.9 \\
*\end{array}$ & $\begin{array}{l}1.75 \\
*\end{array}$ & 0.22 & 10.0 & $\begin{array}{l}112.3 \\
*\end{array}$ & 31.9 & $\begin{array}{l}66.7 \\
*\end{array}$ & 0.32 & 60.4 & 18.5 & 1.19 & 2.67 & 133 & 85.7 & 101.4 \\
\hline SMA & 4.07 & 36.4 & 0.83 & 0.17 & 8.4 & 58.2 & 32.7 & 25.2 & 0.60 & 37.3 & 22.4 & 1.37 & 1.48 & 269 & 42.7 & 61.6 \\
\hline SMA-BH & $\begin{array}{l}6.31 \\
*\end{array}$ & $\begin{array}{l}49.0 \\
*\end{array}$ & $\begin{array}{l}1.24 \\
*\end{array}$ & 0.16 & $\begin{array}{l}12.7 \\
*\end{array}$ & $\begin{array}{l}82.0 \\
*\end{array}$ & 31.0 & $\begin{array}{l}32.7 \\
*\end{array}$ & $\begin{array}{l}0.87 \\
*\end{array}$ & $\begin{array}{l}60.4 \\
*\end{array}$ & 19.6 & $\begin{array}{l}1.80 \\
*\end{array}$ & 1.55 & $\begin{array}{l}74 \\
*\end{array}$ & $\begin{array}{l}64.1 \\
*\end{array}$ & $\begin{array}{l}76.1 \\
*\end{array}$ \\
\hline SAL & 4.99 & 51.3 & 1.33 & 0.20 & 11.5 & 83.3 & 34.5 & 48.5 & 0.34 & 57.9 & 20.8 & 1.46 & 2.34 & 350 & 66.1 & 77.5 \\
\hline SAL-BH & $\begin{array}{l}7.42 \\
*\end{array}$ & 53.5 & $\begin{array}{l}1.83 \\
*\end{array}$ & 0.16 & 14.1 & $\begin{array}{l}106.9 \\
*\end{array}$ & 39.6 & $\begin{array}{l}61.4 \\
*\end{array}$ & 0.54 & 67.8 & 20.6 & 1.79 & 2.60 & $\begin{array}{l}140 \\
*\end{array}$ & $\begin{array}{l}88.6 \\
*\end{array}$ & 92.4 \\
\hline
\end{tabular}

\subsubsection{Radiocarbon dating}

The sample radiocarbon dating $\left({ }^{14} \mathrm{C}\right)$ was performed at the University of Lecce Laboratory (CEDAD) through the AMS technique according to the method described by Calcagnile et al. (2005) and Fiorentino et al. (2008). This included a multistep sample pretreatment in order to remove sources of contamination and to turn the material into graphite. The carbon isotopic ratios $\left({ }^{13} \mathrm{C} /{ }^{12} \mathrm{C}\right.$ expressed as $\delta^{13} \mathrm{C}$ ) were then analyzed by comparing the ${ }^{12} \mathrm{C}$ and ${ }^{13} \mathrm{C}$ ion beam currents, and the sample ${ }^{14} \mathrm{C}$ counts were in turn compared with those obtained for standard reference materials of known isotopic composition (e.g., the fossil wood IAEA C4). Samples of oxalic acid of known concentration given by the National Institute of Standard and Technology were used to perform the quality control of the results. The conventional radiocarbon ages were calculated according to Stuiver and Polach (1977), and then converted to calendar ages by using the latest internationally accepted calibration dataset (Reimer et al. 2004; Blackwell et al. 2006) and the OxCal 3.10 software (Bronk Ramsey 2001; Reimer et al. 2013, 2020). Data are reported in Table 5. cessions. * indicates significant differences between black and nonblack horizons within each site according to Kruskal-Wallis test $(P<0.05)$ 
and sieving through a 5-micron nylon screen; maceration with $10 \%$ hot $\mathrm{KOH}$ solution to remove humic acids; gravity separation with heavy liquid (Thoulet $d=2.1$ ); vacuum filtration on glass fiber papers (Schleicher \& Schuell GF/52); removal of silicates with $40 \% \mathrm{HF}$ for $24 \mathrm{~h}$; and staining with safranin-O and preparation of glycerine fixed slides with Histolaque LMR.

Analyses were carried out under a light microscope (400 and 1000 magnification), and 400-800 pollen/sample was counted. Pollen identification was based on modern and Holocene pollen slide collection, current atlases and pollen keys (e.g., Andersen 1979; Faegri and Iversen 1989; Moore et al. 1994; Reille 1992, 1995), and a large morphopalynological bibliography. The basic pollen terminology was based on Berglund and Ralska-Jasiewiczowa (1986); pollen type names refer to the relevant pollen keys. The main data are synthetically reported in Table 6, whereas the complete dataset is reported in Supplementary Table 4. The term "taxon" is used to indicate both the systematic categories and the morphological pollen types. Plant names refer to Pignatti et al. (2017). Concentrations were reported for pollen and NPPs. Percentage pollen spectra were calculated from the pollen sum, including the total pollen. Pteridophyta percentages were calculated from the pollen sum plus themselves. Table 6 also reports some sums and indices that are significant for the vegetational-ecological interpretation, e.g., trees + shrubs, deciduous broadleaves, animal and human indicators e.g., wild plants (Artemisia, Amaranthaceae, Asteroideae, Cichorioideae, Cirsium, Galium, Plantago, Potentilla type, Ranunculaceae, Rumex, Stellaria type, Urtica dioica) suggesting animal and human presence (Mazier et al. 2006; Mercuri et al. 2013; Florenzano et al. 2015; Deza-Araujo et al. 2021), as well as Hydro-HeloHygrophytes, i.e., plants in humid environments. Pollen clumps were also observed and related to disturbance effects from grazing and trampling, thus representing a proxy for herbivore load (Miehe et al. 2009). NPP identification was based on atlases and keys and relevant bibliography (see Torri, 2011; Miola, 2012). The terms "type" and undiff. (undifferentiated) reported in the spectra were omitted in the text for pollen.

\subsubsection{Black microparticle analyses}

Black microparticles were investigated on the same slides examined for the pollen analyses, and the results are reported in Table 6, and Supplementary Table 4.

Three categories of particles were counted: (1) black particles $=$ wood charcoals $\geq 125 \mu \mathrm{m}$ (maximum $300 \mu \mathrm{m})$; (2) black particles $=$ nonwood charcoals with round edges or sometimes perfectly round $\geq 125 \mu \mathrm{m}$ (maximum $290 \mu \mathrm{m}$ ); and (3) black particles $<125 \mu \mathrm{m}$ undiff. (impossible to separate wood and nonwood). Particles were counted with the method outlined by Torri (2011) with few modifications. More precisely wood and nonwood particles $\geq 125 \mu \mathrm{m}$ were counted on the whole slide separately; black particles undiff. $<125 \mu \mathrm{m}$ were counted together in random rows up to at least 1000 particles. Categories 1 and 2 were interpreted as evidence of local and nearby fires. Category 3 was interpreted as a possible suggestion of fires affecting little

Table 6 Palynological and black particle analyses

\begin{tabular}{|c|c|c|c|c|c|c|c|c|}
\hline \multirow{2}{*}{$\frac{\text { Sites }}{\text { Samples }}$} & & \multicolumn{2}{|l|}{ 1. MRZ } & \multicolumn{2}{|l|}{ 2. SMA } & \multicolumn{3}{|l|}{ 3. SAL } \\
\hline & & \multirow{3}{*}{$\begin{array}{l}\mathrm{AC} \\
40-75\end{array}$} & \multirow{3}{*}{$\begin{array}{l}\text { 2A2 } \\
\text { 100-135 } \\
\text { Black soil }\end{array}$} & \multirow{2}{*}{$\begin{array}{l}6 A 1 b \\
313-330\end{array}$} & \multirow{2}{*}{$\begin{array}{l}6 \mathrm{~A} 2 \mathrm{~b} \\
330-342\end{array}$} & \multirow{3}{*}{$\begin{array}{l}2 \mathrm{AC} 1 \mathrm{~b} \\
360-370\end{array}$} & \multirow{2}{*}{$\begin{array}{l}3 \mathrm{~A} 1 \mathrm{~b} \\
405-427\end{array}$} & \multirow{2}{*}{$\begin{array}{l}6 \mathrm{Ab} \\
730-800\end{array}$} \\
\hline Depth cm & & & & & & & & \\
\hline Buried black soil & & & & Black soil & Black soil & & Black soil & \\
\hline \multirow[t]{2}{*}{ Sums } & Lycopodium spores & 459 & 389 & 1130 & 1016 & 762 & 1569 & 174 \\
\hline & Pollen & 803 & 424 & 417 & 637 & 588 & 659 & 761 \\
\hline \multirow[t]{7}{*}{$\%$ on pollen sum } & Trees + shrubs & 16.8 & 61.8 & 47.2 & 72.1 & 71.6 & 39.6 & 90.9 \\
\hline & Herbs & 83.2 & 38.2 & 52.8 & 27.9 & 28.4 & 60.4 & 9.1 \\
\hline & Conifers & 8.4 & 50.0 & 30.9 & 65.1 & 64.9 & 30.4 & 88.7 \\
\hline & Deciduous broadleaves & 6.0 & 7.8 & 7.4 & 3.8 & 10.1 & 6.7 & 0.9 \\
\hline & Helo-Hygro-Hydrophytes & 2.8 & 3.8 & 4.2 & 2.6 & 2.2 & 1.2 & 0.7 \\
\hline & Animal and human indicators & 67.8 & 19.7 & 19.0 & 7.3 & 14.2 & 40.7 & 4.3 \\
\hline & Pollen clumps & 3.7 & 3.3 & 2.4 & 1.3 & 0.0 & 5.5 & 0.8 \\
\hline$\%$ on pollen sum + themselves & Pteridophyta & 15.5 & 78.5 & 12.5 & 1.2 & 49.8 & 17.9 & 3.4 \\
\hline \multirow[t]{3}{*}{ Concentration (number/g) } & Pollen & 1612 & 1010 & 385 & 674 & 717 & 390 & 4064 \\
\hline & NPPs & 2093 & 997 & 185 & 207 & 1386 & 239 & 655 \\
\hline & Total black particles & 53,800 & 148,734 & 88,458 & 147,076 & 21,611 & 57,858 & 23,225 \\
\hline Climate & & Temperate & Cool dry & Cool dry & Cold dry & Cool dry & Cool dry & Cold dry \\
\hline
\end{tabular}


shrubs, litter, and surface soil, but they could also derive from the breakup of large-sized particles or be transported from far away.

\subsection{Statistical analysis}

To compare the characteristics of buried black horizons with those of the other horizons for each study site and therefore within each stratigraphic sequence, a nonparametric statistical analysis was performed. In particular, a Kruskal-Wallis test was carried out. Within each stratigraphic sequence, the buried black horizons were considered different compared to the other horizons for $P$ values less than 0.05 . The statistical test was performed using the R software.

\subsection{BHs in Emilia, literature research, and study approach}

To better constrain whether and how the studied buried soils were influenced by forcing factors, the new data presented in this study were compared with other data retrieved from the literature concerning other black soil occurrences in surrounding areas. These additional data have been recovered at sites 4 to 10 (Fig. 1), and their physiographic, stratigraphic, and chronological constraints are listed in Supplementary Table 5. As described by the relevant authors (properly quoted in the supplementary section), they are "black soil horizons" that are morphologically similar to the BHs studied in this paper, and their thicknesses rarely exceed the value of $50-60 \mathrm{~cm}$. The geomorphological setting of these additional sites is the same as that of sites 1 to 3 . The radiocarbon dating from site 6 was newly acquired along with that from sites 1 to 3 to provide a time constraint for the related stratigraphic data. Particular emphasis is given to the radiocarbon ages of these BHs to evaluate the possible correspondence between their formation and climatic events or pulses, particularly cold/cool pulses.

Considering the lack of suitable paleoclimatic datasets for the studied geographic area, the $\mathrm{BH}$ dataset (1 to 10 ) was compared with the N-GRIP $\delta^{18} \mathrm{O}$ curve as paleoclimatic reference. Additional constraints were provided by the $\Delta{ }^{14} \mathrm{C}$ residual curve (Stuiver et al. 1998), which is another paleoclimate proxy for the Holocene (e.g., Magny 1993, 1995; Blaauw et al. 2004). In the $\delta^{18} \mathrm{O}$ curve, lower (more negative) values correspond to cold (glacial) periods or cool (Holocene) short climatic pulses, whereas higher values correspond to warmer time. In contrast, $\Delta^{14} \mathrm{C}$ residual curve shows antithetical behavior with positive peaks corresponding to cold periods and vice versa, with the exclusion of 8.2 climatic event having a peculiar origin (Alley and Agustsdottir 2005).

\section{Results}

\subsection{Field observations}

The observations carried out in the field surveys at sites 1-MRZ, 2-SMA, and 3-SAL are summarized in Fig. 3, where radiocarbon dates (see Sect. 4.2.3) are also reported. The subsequent short stratigraphic outlines for each of the three sites are given according to a geographic location ordered from the highest elevation to downstream.

At site 1-MRZ, the bottom deposits are made of gravel representing the bar facies of the Reno riverbed during the Last Glacial Maximum. The uppermost part of the deposit contains slightly weathered marly gravels in a darkened loamy matrix and can be interpreted as a lateral equivalent or the erosional remains of a B $\varnothing$ lling-age reddened soil (Cremaschi 1979; Gasperi et al. 1989; Cremaschi and Nicosia 2012; Ravazzi et al. 2012; Samartin et al. 2012) outcropping on the same terrace in a site located $300 \mathrm{~m}$ to the south. Hence, although no chronometric age for the $3 \mathrm{ABb}$ horizon is available, the morphostratigraphic setting of fluvial terrace Ft3 (see Sect. 2.2) also makes the site $1-\mathrm{MRZ}$ a key pedosequence for constraining the reddened soil whose weathering was allowed only by the peculiar climatic conditions (Samartin et al. 2012; Obase and AbeOuchi 2019) recorded during Greenland Interstadial GI-1e, i.e., the Bølling chronozone (Reimer et al. 2020).

Black soil 2 of site 1-MRZ contains charcoal fragments all along the profile together with $\mathrm{mm}$-sized fragments of fired earthy material, and its uppermost horizon records many slickensides, suggesting a vertic character for this horizon. Soil 2 is capped by a thin, mainly silty, sequence (AC horizon) dating back to between the Chalcolithic and Bronze Ages. Considering the location on the high alluvial terrace, both soil 2 soil and the AC horizon were generated by local splash and sheet erosion of the terrace surface itself together with the nearest hillslope.

For site 2-SMA, it is worth stressing that the survey was performed at the core of a courtyard that is part of a religious complex. The top of the log lies at an elevation $50 \mathrm{~cm}$ higher than the mean floor of the complex (76 m asl) and consists of modern deposits. The underlying stratigraphic units up to a depth of $160 \mathrm{~cm}$ contain ceramic artifacts dating back to the sixteenth to seventeenth centuries AD, and they must be interpreted as artificial leveling deposits linked to various building phases that occurred between the fifteenth and fourteenth centuries AD. No reason exists for supposing that excavations erased pre-existing stratigraphic units; thus, soil 3 of site 2-SMA is the last natural soil containing first Iron Age sherds (ca. seventh century $\mathrm{AD}$ ) and was possibly exposed during the Roman Age and beyond. This long-lasting soil outcropping and its late 
artificial cover are consistent with both the soil 3 thickness and the site physiographic setting, which is a left-hand alluvial terrace lying at a significant elevation above the Aposa stream talweg. Instead, the silty deposits that are the parent material of buried soils 4, 5, and 6 of site 2-SMA can be interpreted as overbank deposits of Aposa or distal colluvial deposits delivered by sandy hillslope degradation. In these soils, well-developed burrowing activity was preserved, thus indicating the lack of agricultural disturbance. For the abovementioned reasons, the main black soil laying at a depth of $3.13 \mathrm{~m}$ was buried at a depth of only $1.5 \mathrm{~m}$ in the past, before the fourteenth century AD.

Site 3-SAL is located near the left shoulder (upper slopebreak) of a wide human-made trench created in the twelfth century $\mathrm{AD}$ to accommodate a commercial harbor for the growing medieval city. These activities removed a massive amount of the natural sedimentary succession (Cremonini et al. 2007). The local refilling of the trench slope degradation is recorded between depths of 2.15 and $3.42 \mathrm{~m}$, whereas the uppermost $2 \mathrm{~m}$ of the sequence is missing due to recent construction activities. The preserved part of the sedimentary succession is almost homogeneously clayey silt (silty loam) and is located at or just beyond the lower margin of the Aposa alluvial fan. Notwithstanding this fine character, and suggesting prominent overbank facies, the local sedimentary aggradation is mainly perceivable thanks to the darkened horizon of the buried soil profiles marking the sedimentary hiatuses linked to the mainstream entrenchment or, more likely, to the lateral shifting of the active depositional fan lobe or alluvial ridge.

\subsection{Results of the analytical investigation}

\subsubsection{Morphological and physicochemical characteristics and carbon speciation}

Within the abovementioned stratigraphic sets at distinct sites, 15 soil cycles were detected, comprising 35 horizons; the related pedological and physicochemical properties are reported in Table 1.

Notably, within the distinct soil cycles, black horizons (BHs) were observed, as they are characterized by a dry Munsell's chart color from 2.5Y3/1 to 2.5Y6/1 (from "very dark gray" to "gray"). In particular, the following nine BHs were recognized: MRZ_2A1 and 2A2 at depths of 75-100 and 100-155 cm at site 1-MRZ; SMA_3A at depths of 135-179 cm; SMA_6A1, 6A2, and 6AC at depths of 313-330, 330-342, and 342-362 cm, respectively, at site 2-SMA; SAL_3A1 and 3A2 at depths of 405-427 and $427-460 \mathrm{~cm}$, respectively; and SAL_6A1 at depths of $738-800 \mathrm{~cm}$ at site 3 -SAL. Below these black horizons, other horizons enriched with both nodules and concretions of $\mathrm{Ca}$-carbonate $(\mathrm{BCk} / \mathrm{Ck})$ are usually recorded.
The $\mathrm{BH}$ at sites 2-SMA and 3-SAL, compared with those associated with the respective stratigraphic sequences, showed more distinctive physicochemical characteristics than those at site 1-MRZ. Generally, they had lower $\mathrm{pH}$ values, $\mathrm{CaCO}_{3}$, and sand contents (Table 1). MRZ_2A1, despite having the typical Munsell color of BHs, appears to be affected by $\mathrm{CaCO}_{3}$ contamination that would derive from soil decarbonation processes of the overlying MRZ_1 soil. Consequently, only MRZ_2A2 showed full characteristics envisaged in other BHs; for this reason, the statistical test for the MRZ sequence was not significant. As shown by the statistical elaboration reported in Table 2 (based on the data fully reported in Supplementary Table 1), BHs differ from the associated horizons, being significantly depleted in $\mathrm{CaCO}_{3}$. For this reason, the correct speciation of total carbon (TC) in its distinct organic and inorganic fractions (TOC and TIC, respectively) is crucial for understanding the considered case study. Both the total composition and fractions were characterized from elemental and isotopic points of view.

The TOC contents of BHs did not show significant differences with respect to the other horizons of the stratigraphic sequences; therefore, organic matter concentration does not appear to be the key explaining the BH peculiarity. In contrast, the $\mathrm{C}$ pools containing inorganic $\mathrm{C}$ (e.g., TIC and TC) were significantly depleted in BHs. Analogously, BHs displayed a more negative $\delta^{13} \mathrm{C}_{\mathrm{TC}}$ compared to overlying and underlying horizons. These differences are highlighted in Fig. 4, which shows the relationship between the TOC/TIC ratios and $\delta^{13} \mathrm{C}_{\mathrm{TC}}$. In this diagram, the $\mathrm{BHs}$ are well separated by the other horizons of the respective stratigraphic succession. An exception is represented by site 1-MRZ, where MRZ-2A1 was contaminated by a concentration of

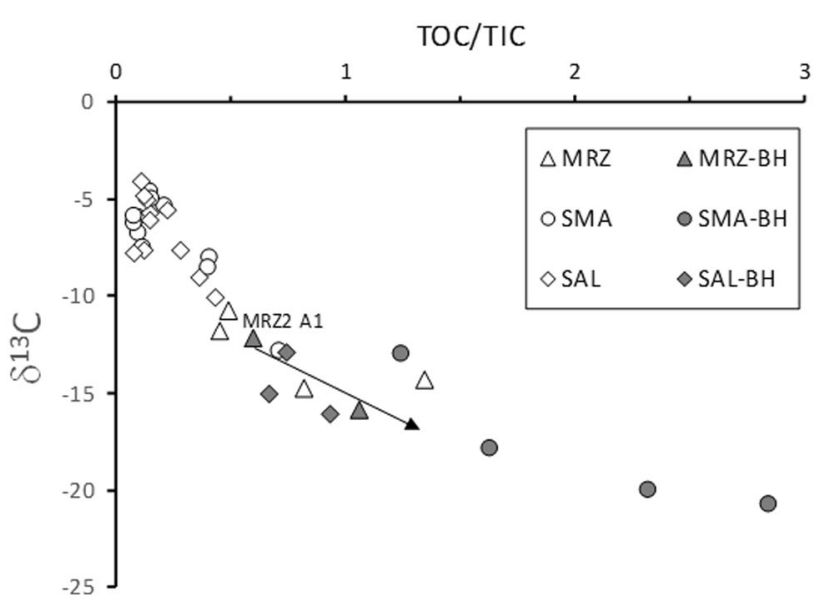

Fig. 4 Binary diagram reporting the TOC/TIC ratio vs. $\delta^{13} \mathrm{C}_{\mathrm{TC}}$, emphasizing the peculiarity of BHs. An arrow has been placed in correspondence with sample MRZ_2A1 to suggest that the pristine features of this horizon have been altered by the late precipitation of carbonate, as testified by field observations 
younger carbonates leached from the overlying soil horizons. The comparatively more negative $\delta^{13} \mathrm{C}_{\mathrm{TC}}$ of $\mathrm{BHs}$ does not merely reflect the paucity of carbonate, because the isotopic compositions of organic and inorganic fractions, $\delta^{13} \mathrm{C}_{\mathrm{TOC}}$ and $\delta^{13} \mathrm{C}_{\mathrm{TIC}}$, respectively, are also peculiarly negative in $\mathrm{BHs}$ (see Supplementary Table 1). Therefore, ${ }^{13} \mathrm{C} /{ }^{12} \mathrm{C}$ differences in the organic fraction favor peculiarly distinct types of vegetation during $\mathrm{BH}$ formation; the signature of vegetation could also have been transferred to the IC fraction during the formation of pedogenic carbonates.

\subsubsection{Major and microelements}

XRF analyses (fully reported in Supplementary Table 2) are effective in differentiating the geochemical nature of BHs with respect to the other soil horizons within each stratigraphic succession. Table 3 underlines, for major elements, the geochemical differences characterizing the BHs. The BHs in site 2-SMA and site 3-SAL were characterized by significantly higher amounts of $\mathrm{SiO}_{2}, \mathrm{TiO}_{2}, \mathrm{Al}_{2} \mathrm{O}_{3}, \mathrm{Fe}_{2} \mathrm{O}_{3}$, and $\mathrm{K}_{2} \mathrm{O}$ and a lower amount of $\mathrm{CaO}$ than the overlying and underlying horizons. On the other hand, statistically, less significant are the differences found in site 1-MRZ.

Moreover, as shown in Fig. 5, the concentration of elements hosted by silica-alumina minerals (e.g., aluminum) is inversely correlated with that of calcium hosted in carbonate.

The microelement data analyzed by ICP-OES on aqua regia leachates are fully reported in Supplementary Table 3, while statistical tests are reported in Table 4 to emphasize $\mathrm{BH}$ peculiarities. It appears that trace elements are also useful to discriminate $\mathrm{BHs}$ from the associated horizons. Many trace elements, such as B, Be, Cr, Li, Ni, Sn, V, and Zn, have higher concentrations in BHs than in other horizons of the respective stratigraphic succession (Table 4). In contrast, in $\mathrm{BHs}, \mathrm{Sr}$, which varies with $\mathrm{Ca}$ in carbonates, is comparatively depleted.

\subsection{3 ${ }^{14} \mathrm{C}$ dating}

The radiocarbon dating performed on the selected soil horizons is listed in Table 5 . In the table, both the $1 \sigma$ and $2 \sigma$ values are reported, but in the subsequent discussion, $2 \sigma$ intervals are taken into account to encompass the maximum age probability, allowing comparison with other chronological data.

At site 1-MRZ, black soil 2 dates back to 6880-6642 calibrated years BP; thus, in terms of northern Italy cultural chronology, it is attributable to the middle Neolithic Age (Pessina and Tinè 2008). At site 2-SMA, black soil 6 shows a date of $15,557-14,872$ calibrated years BP that fits with the Oldest Dryas Chronozone (see Sect. 5.2) or simply the end of glacial stadial GS-2.1 (Rasmussen et al. 2014). Finally, at site 3-SAL, black soil 3 dates back to 25,687-25,083 calibrated years BP, i.e., it is attributable to the Last Glacial Maximum (Shakun and Carlson 2010; Scapozza et al. 2014), which is glacial stadial GS-3 of the last glacial period (Rasmussen et al. 2014).
Fig. $5 \mathrm{CaO}$ vs. $\mathrm{Al}_{2} \mathrm{O}_{3}$ diagram emphasizing the peculiarity of $\mathrm{BHs}$. An arrow has been placed in correspondence with sample MRZ_2A1 to suggest that the pristine features of this horizon have been altered by the late precipitation of carbonate, as testified by field observations

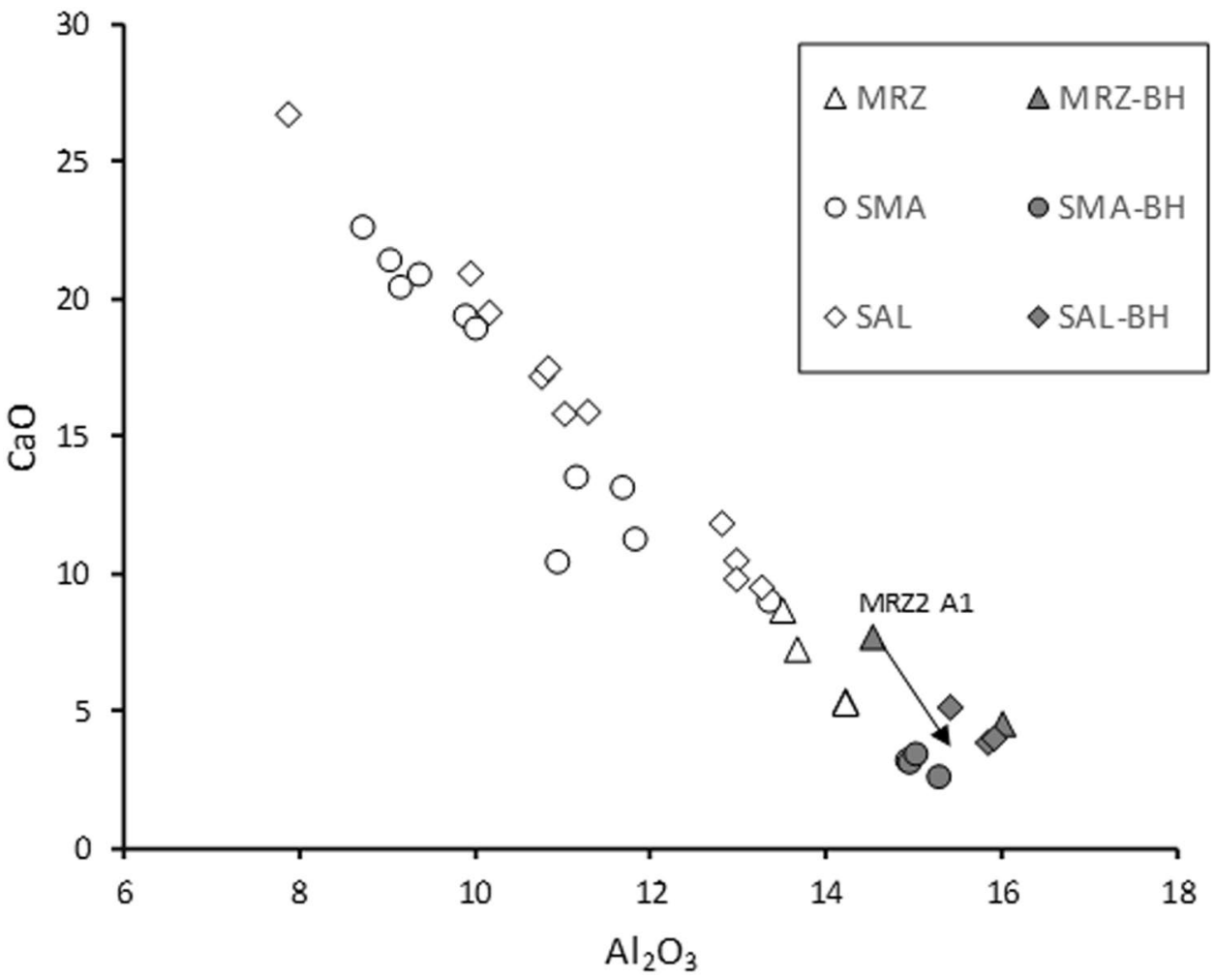




\subsubsection{Palynological and black particle analyses}

In the examined samples, the degree of pollen preservation, diversity, and concentration was high enough to perform a detailed analysis, as synthetized in Table 6 and fully reported in Supplementary Table 4.

Results recorded at site 1-MRZ are listed below.

Horizon AC - pollen assemblage - the forest cover was very low (trees/shrubs $=16.8 \%$ ) and represented by conifers (8.4\%, mainly Pinus sylvestris) and deciduous broadleaves (6.0\%, mainly Corylus avellana and Quercus deciduous). Herbs $(83.2 \%)$ are mainly represented by Cichorioideae, which are interpreted as animal and human indicators (Florenzano et al. 2015; Deza-Araujo et al. 2021), and by pollen clumps indicating disturbance effects from trampling (Miehe et al. 2009).

Hydro-Helo-Hygrophytes are low. NPPs include mainly dinoflagellate algae (see Supplementary Table 4). Black particles are relatively high $(53,800 / \mathrm{g})$ and are mainly represented by undiff. black particles $<125 \mu \mathrm{m}$. The vegetal landscape was an open, steppe-like land with scattered trees/shrubs. Humid environments were scarce. The climate was cool.

Horizon 2A 2 - pollen assemblage - the arboreal pollen increases (trees/shrubs $=61.8 \%$ ) and is mainly represented by conifers $(50.0 \%$, especially Pinus and Abies).

Deciduous broadleaves were low $(7.8 \%)$ and are mainly represented by Corylus. Herbs (38.2\%) are mainly represented by Cichorioideae. Animal and human indicators (see Sect. 3.2.5 and Supplementary Table 4) are moderate and are mainly represented by Cichorioideae and pollen clumps.

Hydro-Helo-Hygrophytes are low. NPPs show a prevalence of dinoflagellate algae (see Supplementary Table 4). Black particles are very abundant $(148,734 / \mathrm{g})$. Among them, undiff. black particles $<125 \mu \mathrm{m}$ prevail, but there is also a good presence of large particles $\geq 125 \mu \mathrm{m}$, indicating local and nearby fires.

The landscape was shaped by a dense forest, mainly made of conifers with some broadleaves. Humid environments were scarce. The climate was cool and dry.

Results recorded at site 2-SMA are listed below.

Horizon $6 \mathrm{~A} 1 \mathrm{~b}$ - pollen assemblage - the forest cover was moderate $(47.2 \%)$. Conifers were dominant (30.9\%, mainly Pinus sylvestris), and deciduous broadleaves were low (7.4\%, mainly Quercus). Herbs (52.8\%) are mainly represented by Asteraceae. Animal and human indicators are moderate and are mainly represented by Cichorioideae with some pollen clumps. Hydro-Helo-Hygrophytes are low. NPPs are few. Black particles are relatively high $(88,458 / \mathrm{g})$. Small particles $\leq 125 \mu \mathrm{m}$ are always the most abundant. The vegetal landscape was a park-like forest with conifers (pines) and some deciduous broadleaves. Humid environments were scarce. The climate was cool and dry.
Horizon $6 \mathrm{~A} 2 \mathrm{~b}$ - pollen assemblage - the forest cover was high $(72.1 \%)$ and mainly formed by conifers $(65.1 \%$, especially Pinus sylvestris). Deciduous broadleaves were very few (3.8\%). Herbs (27.9\%) are mainly represented by Asteraceae. Animal and human indicators are very low. Hydro-Helo-Hygrophytes are low. NPPs are few. Black particles are very high $(147,076 / \mathrm{g})$ and are mainly represented by small particles $<125 \mu \mathrm{m}$. The largest black particles $\geq 125 \mu \mathrm{m}$ are moderate. The landscape was shaped by a dense forest mainly made by conifers. Humid environments were very scarce. The climate was cold and dry.

Results recorded at site 3-SAL are listed below.

Horizon $2 \mathrm{AC} 1 \mathrm{~b}$ - pollen assemblage - the forest cover was high (trees/shrubs $=71.6 \%$ ) and mainly represented by conifers (64.9\%, especially Pinus sylvestris); broadleaves were less represented (10.1\%, mainly Quercus). Herbs are mainly represented by Cichorioideae and Poaceae.

Animal and human indicators are moderate and mainly include Cichorioideae. Pollen clumps are absent. Hydro-Helo-Hygrophytes are very low. NPPs show mainly fungi. Black particles are low $(21,611 / \mathrm{g})$. Among them, small particles $<125 \mu \mathrm{m}$ prevail and are accompanied by some of the largest black particles $\geq 125 \mu \mathrm{m}$. The vegetation landscape was shaped by a mixed forest with dominant conifers with some deciduous broadleaves. Humid environments were very scarce. The climate was cool and dry.

Horizon $3 \mathrm{~A} 1 \mathrm{~b}$ - pollen assemblage - the forest cover was moderate (trees and shrubs $=39.6 \%$ ) and mainly represented by conifers (30.4\%, especially Pinus and Abies). Broadleaves were low (6.7\%, mainly Tilia). Herbs were $60.4 \%$ and mainly represented by Asteroideae. Animal and human indicators are very high and are mainly represented by Cichorioideae, with high pollen clumps. Hydro-HeloHygrophytes are very low. NPPs are very low, mainly fungi. Black particles are relatively high $(57,858 / \mathrm{g})$ and mainly represented by small particles $<125 \mu \mathrm{m}$, while the largest black particles $\geq 125 \mu \mathrm{m}$ are very few. The vegetal landscape was a park-like forest possibly cleared by humans, with conifers and some deciduous broadleaves. Humid environments were very scarce. The climate was cool and dry.

Horizon $6 \mathrm{Ab}$ - pollen assemblage - forest cover was very high (trees/shrubs $=90.9 \%$ ), mainly represented by conifers (88.7\%), especially pines. Deciduous broadleaves were scarce $(0.9 \%)$. Herbs were sporadic. Animal and human indicators are very low. Hydro-Helo-Hygrophytes are very few. NPPs are moderate and mainly include green algae (Zygnemataceae; see Supplementary Table 4). Black particles are low $(23,225 / \mathrm{g})$. Among them, the undiff. black particles $<125 \mu \mathrm{m}$ prevail and are accompanied by a significant amount of the largest particles $\geq 125 \mu \mathrm{m}$. The landscape was shaped by a thick conifer forest mainly made of pines. Humid environments were very scarce. Climate was cold and dry. 
The resulting paleoclimatic picture is also supported by new paleobotanical evidence from the central-eastern Po River alluvial plain (Cacciari et al. 2020). In Fig. 6, a good fitting of the dated site samples with cold or cool episodes can be perceived. In the LGM and Late Glacial, the general climatic conditions were persistent over time and widely encompassed dating uncertainty (sites 2, 3, 5, 6, and 7). In the Holocene, from the Preboreal to Atlantic (sites $1,4,8,9$, and 10), it is more difficult to state if a sample fits well with each time interval of the $\delta^{18} \mathrm{O}$ curve. The better definition of the time-lapse duration of each worsening episode suggested by the residual $\Delta{ }^{14} \mathrm{C}$ curve allows us to recognize a more evident correlatability. On the eastern side of the city area, the $\mathrm{BH}$ samples from sites 5, 6, and 7 have similar ages (Allerød/Younger Dryas transition), and they could truly be mutually correlatable. Site 9 is not represented by a single sample but by a set of samples and hence possesses only a descriptive value for pedogenetic episodes and a consequently low reliability. The site 4 sample can be associated with the $9.3 \mathrm{ky}$ BP pulse as well as the site 8 sample, whereas the site $10 \mathrm{~b}$ sample is consistent with the $8.2 \mathrm{ky} \mathrm{BP}$ (boreal) pulse. The site 10a sample and possibly site 1-MRZ appear to be correlatable to the Atlantic chronozone pulse (Early Neolithic).

\section{Discussion}

\subsection{Timing of BH development in Emilia}

As reported by Fig. 6, the cool pulses appear to have a 150-200-year duration according to the $\delta^{18} \mathrm{O}$ curve, or $700-800$ years according to the $\Delta^{14} \mathrm{C}$ curve. The duration of these time lapses seems suitable for $\mathrm{BH}$ genesis (Duchaufour 1968). The two samples from site 10 (/a and /b) can support this idea; in fact, they are horizons of the same soil profile but show an age difference of approximately 600 years without any appreciable sediment addition, thus suggesting the existence of a topdown time gradient depending on the SOM turnover and mean residence time (e.g., Vysloužilová et al. 2016). The site 1-MRZ sample shows an age falling at the youngest limit of the Atlantic worsening pulse, or just beyond it. In this case, its true inception age could predate the available ${ }^{14} \mathrm{C}$ age. Regardless, this soil seems to be the last that display morphological characteristics of the profile similar to that of the more ancient site samples (thickness, color, and $\mathrm{CaCO}_{3}$ concentration). Possibly, after the Chalcolithic Age, both climate characteristics and ancient human impact on the Reno River valley (Eppes et al. 2008) did not ever allow the development of similar $\mathrm{BH}$ soils.

\subsection{Vegetation and climate inferred by palynological and black particle records}

The site 1-MRZ series shows the transition from a dense forest, mainly conifers in a cool climate with important local and nearby fires, to a steppe-like land that was likely due to human clearance in a temperate climate. The black particles are more abundant in the buried black soil (Table 6), indicating significant episodes of biomass burning.

The site 2-SMA series shows the transition from a thick forest, mainly represented by conifers in a cold and dry climate, to a park-like forest that was probably derived from human clearance, during a cool and dry climate. Black particles are more abundant in the deepest buried black soil, indicating significant episodes of biomass burning.

The site 3-SAL series shows first the transition from a very thick conifer forest with some local and nearby fires in a cold and dry climate to a park-like forest probably due to human clearance, with dominant conifers and some deciduous broadleaves in a cool and dry climate. Subsequently, there has been a re-increase in forests with dominant conifers and deciduous broadleaves in a cool and dry climate.

Based on palynological and black particle analyses, buried black soils appear to be characterized by variously dense forest with prevalent conifers, scarce humid environments, and a cold or cool dry climate. Considering the recorded ${ }^{14} \mathrm{C}$ ages of the studied $\mathrm{BHs}$, the hypothesis is compatible with findings observed in sediments and paleosols from other localities in Emilia Romagna (Accorsi et al. 1996, 1999; Amorosi et al. 2001; Vittori Antisari et al. 2016) and more generally in northern Italy (Pini 2002; Serandrei-Barbero et al. 2005; Ravazzi et al. 2012; Guido et al. 2020; Marcolla et al. 2021). The high presence of undiff. black particles $<125 \mu \mathrm{m}$ was probably due to fires affecting shrubs, litter, and surface soil.

However, the above reported landscape reconstructions should be taken with caution. In fact, direct comparisons with other pollen diagrams or spectra of northern Italy were not possible because pollen diagrams or single spectra also reporting wood and nonwood black microparticles were not available.

\subsection{Black horizon genetic process}

The chronological framework resulting from sites 1 to 10 indicates that the recorded pedological features are not related to a single pedogenetic phase, but rather they are repeatedly triggered during the Late Glacial and the Holocene in connection with worsening climatic pulses 
Fig. 6 Black soil chronology and paleoclimatic setting relationships. The horizontal black bars suggest the $2 \sigma$ radiocarbon age for each site sample, as reported in Supplementary Table 5. A Plot of the $\delta^{18} \mathrm{O}$ variation from the N-GRIP core dataset: raw data after Svensson et al. (2008). The gray color is the envelope of the raw data; the central solid line is the ten-unit running mean of the raw data. Data refer to 1950 and not to 2000. B Details of panel A showing the original raw dataset between 16 and $6 \mathrm{ky}$ BP. C Variation plot of residual $\Delta{ }^{14} \mathrm{C}$ concentration from the GISP dataset (http://www.ncdc.noaa.gov/ paleo/icecore/greenland/summit/ document/gripisot.htm.). The solid line is the ten-unit running mean of the original raw data
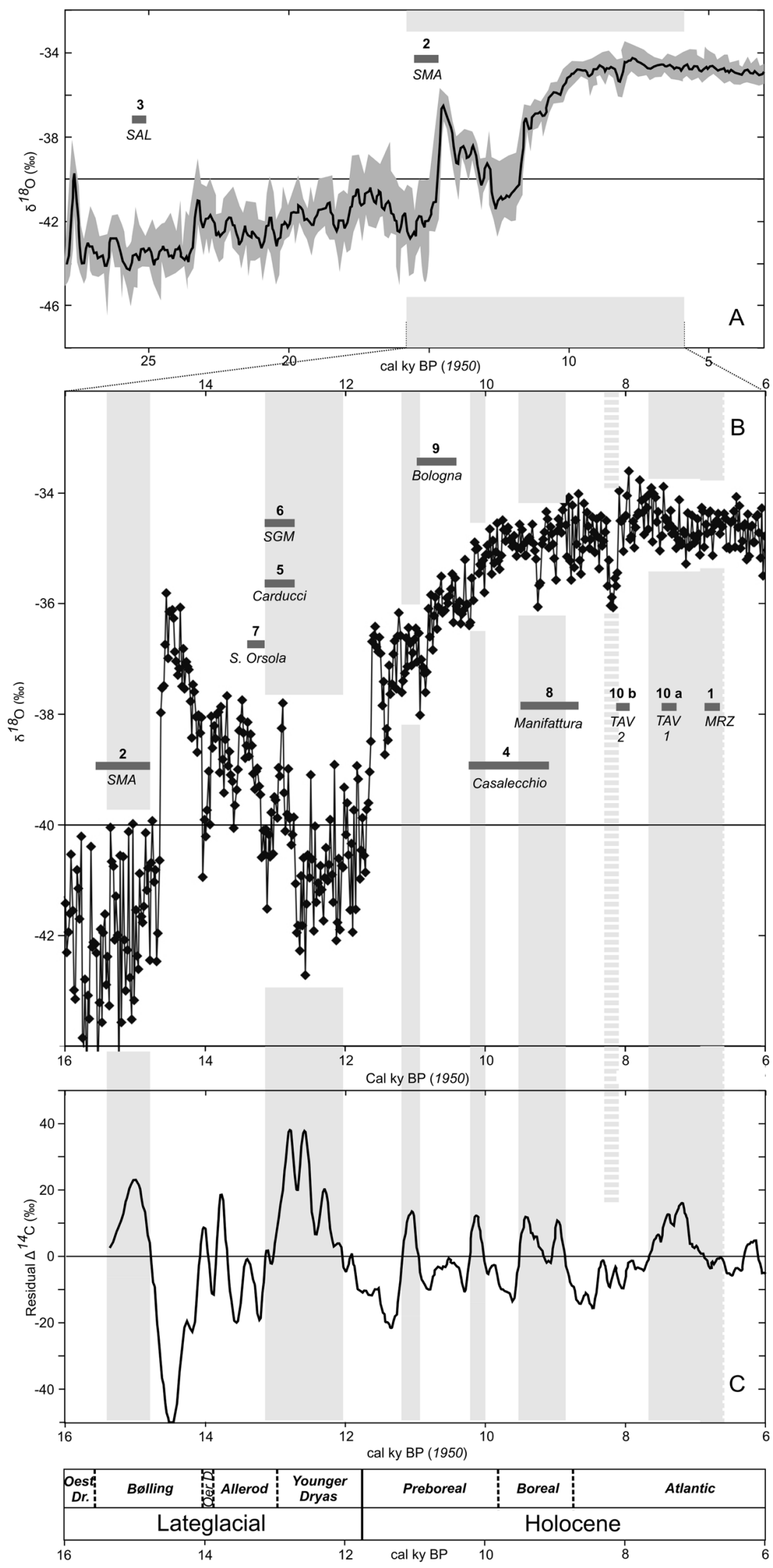
characterized by temperature decreases, as also confirmed by deep coring (Bruno et al. 2020; Marcolla et al. 2021).

Notably, the key BH character, with respect to the overlying and underlying horizons, is the paucity of carbonate (also measured in terms of TIC and Ca), which seems to be related to both sedimentological and subsequent pedological processes. The scarcity of carbonate was related to the interaction with acidic- $\mathrm{CO}_{2}$-rich-water (Ulery et al. 1993) due to the leaching processes operated by rainfall water infiltrating the acidic soil typical of pine forest biomes (Nilsson et al. 1982; Hornung 1985; Binkley 1996; Godbold et al. 2003) during cold periods and cool phases.

Carbon isotopes of $\mathrm{BH}$ are in fact characterized by $\delta^{13} \mathrm{C}$ values that are more negative with respect to the overlying and underlying horizons. This is in primis related to the scarcity of the inorganic carbon fraction, which is always characterized by $\delta^{13} \mathrm{C}$ values that are less negative than the associated organic fraction. However, the isotopic analysis of the organic fraction also shows more negative $\delta^{13} \mathrm{C}_{\mathrm{TOC}}$ values for $\mathrm{BHs}$, a feature necessarily implying a difference in pristine vegetation. This means that during the genesis of BHs, the vegetation was richer in $\mathrm{C} 3$ plants (having an average $\delta^{13} \mathrm{C}$ of $-25 \%$ ) than in $\mathrm{C} 4$ plants (having an average $\delta^{13} \mathrm{C}$ of $-15 \%$ ), as usually noticed during cold periods (Meier et al., 2014). Thus, during BH formation, an arboreal association prevailed with respect to grassy cover, as corroborated by pollen investigation invariably showing pine-rich vegetation. Moreover, in BHs, the concentration of most trace elements (except $\mathrm{Sr}$, which covariates with $\mathrm{Ca}$ ) is always comparatively enriched but with variable enrichment factors, probably depending on a distinct involvement of each element in leaching processes.

The black particle investigation also revealed a significant concentration of microcharcoal in BHs. This means that during $\mathrm{BH}$ formation, the recorded pine forest cover was affected by natural fires (e.g., Badino et al. 2020), as still observed nowadays (Sofronov et al. 1998), or even fires of human-induced origin, as envisaged in many other case studies (Piquè et al. 2020; Aranbarri et al. 2020). In the European framework, the charcoal frequency severely increased during the Holocene (Power 2013), already dating back to pre-Neolithic times (Gerlach et al. 2012; Guido et al. 2013; Brandt et al. 2014) when the vegetation burning practice could have also been due to the hunter-gatherer community feeding approach (Tolksdorf et al. 2014). In the case of site 1-MRZ, dating back to the Neolithic and showing the maximum concentration of black particles, human activities (Rösch et al. 2002; Cremaschi and Nicosia 2012; Robinson 2014; Jacomet et al. 2016) can be suggested. In such a case, this could be the first evidence in the region of the human impact on the environment. In fact, according to previous investigations, in Emilia, only the Chalcolithic recorded the beginning of a severe human impact on the landscape (Cremaschi and Nicosia 2012; Zanchetta et al. 2013). In the case of the older site 2-SMA and site 3-SLA, the drivers are more plausibly triggered by natural causes (Zhao et al. 2021; Resco de Dios et al. 2021), even if some studies speculate that anthropogenic activities influenced the fire regime even in pre-Holocene times (Kaplan et al. 2016; Sorensen 2017). Regardless of the origin of fires, the effect of combustion on soils was the partial transformation of organic matter and organometallic compounds in recalcitrant black carbon (the microcharcoal particles), a process that plausibly contributed to enriching many trace element concentrations in BHs. Accordingly, Giovannini et al. (1988) proposed that distillation and volatilization processes of soil organic matter occur between 100 and $200^{\circ} \mathrm{C}$, whereas higher temperatures induce carbonization and structural variation in humic and fulvic acids (Almendros et al. 1990), with the formation of pyromorphic compounds that are less affected by microbial degradation. Fire would also lead to destruction of colloids, collapse of organomineral aggregates, and a subsequent increase in density, with loss of $\mathrm{C}$ and $\mathrm{N}$ (Natali et al. 2021) and an increase in metals such as $\mathrm{Al}, \mathrm{Fe}, \mathrm{Ti}, \mathrm{Cr}, \mathrm{Ni}, \mathrm{Sn}, \mathrm{V}$, and $\mathrm{Zn}$. Therefore, the dark color of BHs is due to both the microcharcoal concentration and the effect of organic matter burning and its consequent transformation.

\section{Conclusions}

BHs are recurrent in soil sequences in the areas surrounding Bologna at various depths. Their dark color is not related to an excess of organic matter, but to low concentration of carbonate and the peculiar presence of microcharcoal.

Our review of BHs in the areas surrounding Bologna provides a tool to evaluate climatic changes that occurred during the Late Glacial-Holocene period.

Geochemical, isotopic, and palynological/black particle evidence demonstrates that BHs invariably form over a time lapse of a few hundred years during cold/cool periods. This is corroborated by the comparison of the available $\mathrm{BH}$ radiocarbon age with climatic curves based on isotopic evidence (e.g., $\delta^{18} \mathrm{O}$ and residual $\Delta^{14} \mathrm{C}$ ). In fact, these ages generally fit well with the cold periods retrieved by isotopic datasets. The studied BHs and their microcharcoal contents also provide interesting insights into the peculiar processes of vegetation fires, which seem to have been recurrent during the Late Glacial and the Holocene. Such a recurrence could have been of natural origin, but possibly also facilitated by early human activities, in particular from the Neolithic onward. Our research will continue tackling the same approach for more BHs in the surrounding areas to constrain the delineated hypotheses with more data. 
Supplementary information The online version contains supplementary material available at https://doi.org/10.1007/s11368-021-03088-6.

Acknowledgements We thank Dr. P. Desantis, Dr. T. Trocchi (Soprintendenza ai Beni Archeologici dell'Emilia-Romagna during years 20142015, now SABAP), and Prof. E. Govi (Dipartimento di Archeologia e Cultura del Mondo Antico - Università degli Studi di Bologna) for the permission of performing the geological observations concerning the site 1 (archeological area of Marzabotto) as well as site 2 and the related permission of geological data publication. The authors gratefully acknowledge the anonymous referees for the constructive comments contained in their reviews and the editors for their careful editing.

Funding Open access funding provided by Università degli Studi di Ferrara within the CRUI-CARE Agreement. Part of the research was funded by "ex RFO-60\% years 2015-2016 and year 2017" of the Bologna University and FFABR 2017 (person in charge Cremonini S.).

Open Access This article is licensed under a Creative Commons Attribution 4.0 International License, which permits use, sharing, adaptation, distribution and reproduction in any medium or format, as long as you give appropriate credit to the original author(s) and the source, provide a link to the Creative Commons licence, and indicate if changes were made. The images or other third party material in this article are included in the article's Creative Commons licence, unless indicated otherwise in a credit line to the material. If material is not included in the article's Creative Commons licence and your intended use is not permitted by statutory regulation or exceeds the permitted use, you will need to obtain permission directly from the copyright holder. To view a copy of this licence, visit http://creativecommons.org/licenses/by/4.0/.

\section{References}

Alley RB, Agustsdottir AM (2005) The 8k event: cause and consequences of a major Holocene abrupt climate change. Quat Sci Rev 24:1123-1149. https://doi.org/10.1016/j.quascirev.2004.12. 004

Accorsi CA, Bandini Mazzanti M, Mercuri AM, Rivalenti C, Trevisan Grandi G (1996) Holocene forest pollen vegetation of the Po Plain - Northern Italy (Emilia Romagna data) Allionia 34: $233-276$

Accorsi CA, Mazzanti M, Forlani L, Mercuri AM, Trevisan Grandi G (1999) An overview of Holocene Forest Pollen Flora/Vegetation of the Emilia Romagna Region - Northern Italy, Archivio Geobotanico, 5:3-37, ISSN 1122-7214

Almendros G, Gonzáles-Vila FJ, Martín F (1990) Fire-induced transformation of soil organic matter from an oak forest: an experimental approach to the effects of fire on humic substances. Soil Sci 149:158-168. https://doi.org/10.1097/ 00010694-199003000-00005

Amorosi A, Forlani L, Fusco F, Severi P (2001) Cyclic patterns of facies and pollen associations from Late Quaternary deposits in the subsurface of Bologna. GeoActa 1:83-94

Amorosi A, Bruno L, Bruno C, Morelli A, Hong W (2014a) The value of pocket penetration tests for the high-resolution palaeosol stratigraphy of late Quaternary deposits. Geol J 50:670-682. https:// doi.org/10.1002/gj.2585

Amorosi A, Bruno L, Rossi V, Severi P, Hajdas I (2014b) Paleosol architecture of a late Quaternary basin-margin sequence and its implications for high-resolution, non-marine sequence stratigraphy. Glob Planet Change 112:12-25. https://doi.org/10. 1016/j.gloplacha.2013.10.007

Amorosi A, Brun L, Cleveland DM, Morelli A, Hong W (2017) Paleosols and associated channel-belt sand bodies from a continuously subsiding late Quaternary system (Po Basin, Italy): new insights into continental sequence stratigraphy. Geol Soc Am Bull 129:449-463. https://doi.org/10.1130/B31575.1

Andersen ST (1979) Identification of wild grass and cereal pollen (fossil pollen, Annulus diameter, surface sculpturing). Danmarks Geologiske Undersøgelse, Årbog, pp 69-92

Aranbarri J, Alcolea M, Badal E, Vila S, Allué E, Iriarte-Chiapusso MJ, Sebastian M, Magri D, Gonzalez-Samperiz P (2020) Holocene history of Aleppo pine (Pinus halepensis Mill.) woodlands in the Ebro Basin (NE Spain): climate-biased or human-induced? Rev Palaeobot Palynol 279: 104240. https://doi.org/10.1016/j. revpalbo.2020.104240

Armas-Herrera CM, Pérez Lambán F, Badía Villas D, Peña Monné JL, González Pérez JA, Picazo JV, Jiménez Morillo NT, Sampietro Vattuone MM, Alcolea Gracia M (2019) Pyrogenic organic matter from paleo-fires during the Holocene: a case study in a sequence of buried soils at the Central Ebro Basin (NE-Spain). J Environ Manage 241:558-566. https://doi.org/ 10.1016/j.jenvman.2018.09.104

Badino F, Pini R, Bertuletti P, Ravazzi C, Delmonte B, Monetato G, Reimer P, Vallé F, Arrighi S, Bortolini E, Figus C, Lugli F, Maggi V, Marciani G, Margaritora D, Oxilia G, Romandini M, Silvestrini S, Benazzi S (2020) The fast-acting "pulse" of Heinrich Stadial 3 in a mid-latitude boreal Ecosystem. Nature Res Sci Rep 10:18031, 14. https://doi.org/10.1038/s41598-020-74905-0

Berglund BE, Ralska-Jasiewiczowa M (1986) Pollen analysis and pollen diagrams. In: Berglund BE (ed) Handbook of Holocene Palaeoecology and Palaeohydrology. John Wiley and Sons Press, Chichester, pp 455-484

Bertani MG (2010) Le ristrutturazioni. Govi E and Sassatelli G (Eds), Marzabotto. La casa 1 della Regio IV-Insula 2: 1- Lo scavo. Studi e Scavi del Dipartimento di Archeologia - Alma Mater Studiorum 26: 21-25. SBN 978-88-7849-057-4

Bianchini G, Cremonini S, Di Giuseppe D, Vianello G, Vittori Antisari L (2014) Multiproxy investigation of a Holocene sedimentary sequence near Ferrara (Italy): clues on the physiographic evolution of the eastern Padanian plain Journal of Soils and Sediments. J Soil Sediment 14:230-242. https://doi.org/10.1007/ s11368-013-0791-2

Bianchini G, Cremonini S, Di Giuseppe D, Gabusi R, Marchesini M, Vianello G, Vittori Antisari L (2019) Late Holocene palaeoenvironmental reconstruction and human settlement in the eastern Po Plain (northern Italy) Catena 176: 324-335. https://doi. org/10.1016/j.catena.2019.01.025

Binkley D (1996) The influence of tree species on forest soils: processes and patterns. In: D.J. Mead, and I.S. Cornforth (Eds.) Proceedings of the trees and soils workshop (pp 1-33), Agronomy Society of New Zealand Special Publication \#10, Canterbury

Binney H, Edwards M, Macias-Fauri M, Lozhkin A, Anderson P, Kapla JO, Andreev A, Bezrukova E, Blyakharchuk T, Jankovska V, Khazina I, Krivonogov S, Kremenetski K, Nield J, Novenko E, Ryabogina N, Solovieva N, Willis K, Zernitskaya V (2017) Vegetation of Eurasia from the last glacial maximum to present: key biogeographic patterns. Quat Sci Rev 157:80-97. https://doi.org/ 10.1016/j.quascirev.2016.11.022

Blaauw M, van Geel B, van der Plicht J (2004) Solar forcing of climatic change during the mid-Holocene: indications from raised bogs in The Netherlands. The Holocene 14:35-44. https://doi.org/10. 1191/0959683604h1687rp

Blackwell PG, Buck CE, Reimer P (2006) Important features of the new radiocarbon calibration curves. Quat Sc Rev 25:408-413. https://doi.org/10.1016/j.quascirev.2005.12.001 
Boccaletti M, Coli M, Eva C, Ferrari G, Giglia G, Lazzaretto A, Merlanti F, Nicolic R, Papani G, Postpischl D (1985) Considerations on the seismotectonics of the Northern Apennines. Tectonophysics 117:7-38. https://doi.org/10.1016/0040-1951(85)90234-3

Brandt G, Széecséenyi-Nagy A, Roth C, Alt KW, Haak W (2014) Human paleogenetics of Europe - the known knowns and the known unknowns. J Hum Evol 79:73-92. https://doi.org/10. 1016/j.jhevol.2014.06.017

Bronk RC (2001) Development of the radiocarbon program OxCal. Radiocarbon 43:355-363. https://doi.org/10.1017/S0033822200038212

Bruno L, Marchi M, Bertolini I, Gottardi G, Amorosi A (2020) Climate control on stacked paleosols in the Pleistocene of the Po Basin (northern Italy). J Quat Sci 35(4):559-571

Cacciari M, Cremonini S, Marchesini M, Vianello G, Vittori Antisari L (2017) When a pedomarker is lacking: palynological and chemical multianalysis of a Lateglacial-Holocene buried soil suite (Bologna, Italy). EQA 24:47-73. https://doi.org/10.6092/issn.2281-4485/ 7599

Cacciari M, Amorosi A, Marchesini M, Kaniewshi D, Bruno L, Campo B, Rossi V (2020) Linking Holocene vegetation dynamics, palaeoclimate variability and depositional patterns in coastal successions: insights from the Po Delta plain of Northern Italy. Palaeogeog Palaeoclimatol Palaeoecol 538:109468. https://doi.org/ 10.1016/j.palaeo.2019.109468

Calcagnile L, Quarta G, D'Elia M (2005) High resolution acceleratorbased mass spectrometry: precision accuracy and background. Appl Radiat Isot 62:623-629. https://doi.org/10.1016/j.apradiso. 2004.08.047

Carminati E, Martinelli G (2002) Subsidence rates in the Po Plain, northern Italy: the relative impact of natural and anthropogenic causation. Eng Geol 66:241-255. https://doi.org/10.1016/S00137952(02)00031-5

Carminati E, Vadacca (2010) Two- and three-dimensional numerical simulations of the stress field at the thrust front of the northern Apennines. Italy J Geophys Res 115:B12425. https://doi.org/10. 1029/2010JB007870

Cattani M, Govi E (2010) Gli antefatti dell'età del Bronzo. Govi E and Sassatelli G (Eds.), Marzabotto. La casa 1 della Regio IV-Insula 2: 1- Lo scavo. Studi e Scavi del Dipartimento di Archeologia Alma Mater Studiorum 26: 13-19. ISBN 978-88-7849-057-4

Chendev Y, Khokhlova O, Ponomarenko E, Ershova E, Alexandrovskiy A, Myakshina T (2018) Holocene environmental and anthropogenic changes of soils and vegetation in the Central Russian Upland: the case study in the "Belogorie" Natural Reserve. Geosciences 8: 473. https://doi.org/10.3390/geosciences8120473

Clark PU, Shakun JD, Baker PA, Bartlein PJ, Brewer S, Brook E, Carlson E, Chengh H, Kaufman DS, Liu Z, Marchitto M, Mix A, Morrill C, Otto-Bliesner BL, Pahnke K, Russell M, Whitlock C, Adkin JF, Blois JL, Clark J, Colman SM, Curry WB, Flower BP, H F, Johnson TC, Lynch-Stieglitz J, Markgraf V, McManus J, Mitrovica JX, Moreno PI, Williams JW (2012) Global climate evolution during the last deglaciation. PNAS 109:E1134-E1142. https://doi.org/10.1073/pnas.1116619109

Costantini EAC, Fantappiè M, L'Abate G (2013) Climate and pedoclimate in Italy. Costantini E.A.C., Dazzi C. (Eds.), The soils of Italy. Springer, 19-37. ISBN 978-94-007-5642-7

Cremaschi M (1979) Alcune osservazioni sul paleosuolo delle conoidi "würmiane" poste al piede dell'Appennino emiliano. Geogr Fis Din Quat 2:187-195

Cremaschi M, Nicosia C (2012) Sub-Boreal aggradation along the Apennine margin of the Central Po Plain: geomorphological and geoarchaeological aspects. Géomorphologie 18:155-174. https:// doi.org/10.4000/geomorphologie. 9810

Cremonini S (1991) Il torrente Savena oltre i limiti dell'analisi storica. Un esempio di "Archeologia fluviale". Atti e Memorie. Deputazione Di Storia Patria per Le Province Di Romagna 42:159-205
Cremonini S (2002) Il quadro geo-pedologico di Via FoscoloFrassinago: indicazioni sull'evoluzione geomorfologica del pedecolle e del centro storico di Bologna negli ultimi 3000 anni. In "Lo scavo archeologico di Via Foscolo-Frassinago a Bologna: aspetti insediativi e cultura materiale" a cura di Ortalli J e Pini L, Quaderni di Archeologia dell'Emilia Romagna 7: 119-141. ISBN: 9788878142848

Cremonini S, Lorito S, Vianello G, Vittori Antisari L, Fusco F (2007) Suoli olocenici sepolti nel centro urbano di Bologna. Prime considerazioni pedologiche e radiometriche. Gessa C, Lorito S, Vianello G, Vittori Antisari L (Eds), "Suolo, ambiente, paesaggio", Atti Conv Naz Soc It Sc Suolo, Imola 27-30 Giugno 2006: 48-56. ISBN: 9788878142848

Cremonini S, Bracci EA (2010) Problemi di paleoidrografia in ambito urbano. Bologna: rassegna critica di ipotesi e nuovi dati. In "Alla ricerca di Bologna antica e medievale - da Felsina a Bononia negli scavi di via D’Azeglio" a cura di L Malnati, R Curina, C Negrelli, L Pini. Quaderni di Archeologia dell'Emilia Romagna 25: 167-176. ISBN 9788878144163

D’Anastasio E, De Martini PM, Selvaggi G, Pantosti D, Marchioni A, Maseroli R (2006) Short-term vertical velocity field in the Apennines (Italy) revealed by geodetic levelling data. Tectonophysics 418:219-234. https://doi.org/10.1016/j.tecto.2006.02.008

Deza-Araujo M, Morales-Molino C, Conedera M, Pezzatti GB, Pasta S, Tinner W (2021) Influence of taxonomic resolution on the value of anthropogenic pollen indicators. Veg Hist Archaeobot. https:// doi.org/10.1007/s00334-021-00838-x

Di Giuseppe D, Bianchini G, Faccini B, Coltorti M (2014) Combination of WDXRF analysis and multivariate statistic for alluvial soils classification: a case study from the Padanian Plain (Northern Italy). X-Ray Spectrom 43:165-174. https://doi.org/10.1002/xrs. 2535

Duchaufour P (1968) L'evolution des sols. Essai sur la dynamique des profiles. Masson et Cie, Paris, p 94

Eppes MC, Bierma R, Vinson D, Pazzaglia F (2008) A soil chronosequence study of the Reno valley, Italy: insights into the relative role of climate versus anthropogenic forcing on hillslope processes during the mid-Holocene. Geoderma 147:97-107. https:// doi.org/10.1016/J.GEODERMA.2008.07.011

Faegri K, Iversen J (1989) Textbook of pollen analysis, IV ed., Faegri K, Kaland PE and Krzywinski K (Eds). John Wiley and Sons LTD, Chichester

Fantoni R, Franciosi R (2010) Tectono-sedimentary setting of the Po Plain and Adriatic Foreland. Rend Fis Acc Lincei 21:197-209. https://doi.org/10.1007/s12210-010-0102-4

Fiorentino G, Caracuta V, Calcagnile L, D'Elia M, Matthiae P, Mavelli F, Quarta G (2008) Third millennium B.C. climate change in Syria highlighted by carbon stable isotope analysis of 14C-AMS dated plant remains from Ebla. Palaeogeogr Palaeoclimatol Palaeoecol 266:51-58. https://doi.org/10.1016/j.palaeo.2008.03.034

Florenzano A, Marignani M, Rosati L, Fascetti S (2015) Are Cichorieae an indicator of open habitats and pastoralism in current and past vegetation studies? Plant Biosystems 149:154-165. https:// doi.org/10.1080/11263504.2014.998311

Gasperi G, Cremaschi M, Mantovani Uguzzon MP, Cardarelli A, Cattani M, Labate D (1989) Evoluzione plio-quaternaria del margine appenninico modenese e dell' antistante pianura. Note illustrative alla carta geologica. Mem Soc Geol It 29:375-431

Gee GW, Bauder JW (1986) In: Klute, A (ed). Methods of soil analysis. Physical and mineralogical methods. Agronomy Monograph 9 (2ed). American Society of Agronomy, Madison, WI, USA

Gerlach R, Fischer P, Eckmeier E, Hilgers A (2012) Buried dark soil horizons and archaeological features in the Neolithic settlement region of the Lower Rhine area, NW Germany: formation, geochemistry and chronostratigraphy. Quatern Int 265:191-204. https://doi.org/10.1016/j.quaint.2011.10.007 
Ghielmi M, Minervini M, Nini C, Rogledi S, Rossi M, Vignolo A (2010) Sedimentary and tectonic evolution in the eastern Po-Plain and northern Adriatic Sea area from Messinian to middle Pleistocene (Italy). Rend Fis Acc Lincei 21:131-166. https://doi.org/10.1007/ s12210-010-0101-5

Ghielmi M, Minervini M, Nini C, Rogledi S, Rossi M (2012) Late Miocene. Middle Pleistocene sequences in the Po Plain e Northern Adriatic Sea (Italy): the stratigraphic record of modification phases affecting a complex foreland basin. Mar Petrol Geol 42:50-81. https://doi.org/10.1016/j.marpetgeo.2012.11.007

Giorgi G (2002) Man-induced changes in urban geomorphology: the historic centre of Bologna (Italy). Geografia Fisica Dinamica Quaternaria 25: 111-121. ISSN 0391-9838, 20021

Giovannini G, Lucchesi S, Giachetti M (1988) Effect of heating on some chemical parameters related to soil aggregation and erodibility. Soil Sci 146: 255-261. ISSN: 0038-075X

Giuffra V, Fornaciari A, Marvelli S, Marchesini M, Fornaciari G, Vitiello A (2011) The children of the Medici, Grand Dukes of Florence: embalming in Renaissance Italy (XVI-XVII century). Atti Soc Tosc Sci Nat, Mem, Serie B 118:81-88. https://doi.org/ 10.2424/ASTSN.M.2011.26

Godbold DL, Fritz H-W, Jentschke G, Meesenburg H, Rademacher P (2003) Root turnover and root necromass accumulation of Norway spruce (Picea abies) are affected by soil acidity. Tree Physiol 23:915-921. https://doi.org/10.1093/treephys/23.13.915

Guido MA, Menozzi BI, Bellini C, Montanari CA (2013) A palynological contribution to the environmental archaeology of a Mediterranean mountain wetland (North West Apennines, Italy). The Holocene 23:1517-1527. https://doi.org/10.1177/0959683613496294

Guido MA, Molinari C, Moneta V, Branch N, Black S, Simmonds SP, Montanari C (2020) Climate and vegetation dynamics of the Northern Apennines during Late Pleistocene and Holocene. Quat Sci Rev 231:106206. https://doi.org/10.1016/j.quascirev. 2020.106206

Gunderson KL, Pazzaglia FJ, Picotti V, Anastasio DA, Kodama KP, Rittenour T, Frankel KF, Ponza A, Berti C, Negri A, Sabbatici A (2014) Unraveling tectonic and climatic controls on synorogenic growth strata (Northern Apennines. Italy). Geol Soc Am Bull 126:532-552. https://doi.org/10.1130/B30902.1

Hornung M (1985) Acidification of soils by trees and forests. Soil Use Manag 1:24-27. https://doi.org/10.1111/j.1475-2743.1985. tb00648.x

Jacomet S, Ebersbach R, Akeret Ö, Antolín F, Baum T, Bogaard A, Brombacher C, Bleicher NK, Heitz-Weniger A, Hüster-Plogmann H, Gross E, Kühn M, Rentzel P, Steiner BL, Wick L, Schiblerl JM (2016) On-site data cast doubts on the hypothesis of shifting cultivation in the late Neolithic (c. 4300-2400 cal. BC): landscape management as an alternative paradigm. The Holocene 26, 1858-1874. https://doi.org/10.1177/0959683616645941

Joannin S, Vannière B, Galop D, Peyron O, Haas JN, Gilli A, Chapron E, Wirth SB, Anselmetti F, Desmet M, Magny M (2013) Climate and vegetation changes during the Lateglacial and early-middle Holocene at Lake Ledro (southern Alps, Italy). Clim past 9:913933. https://doi.org/10.5194/cp-9-913-2013

Kaplan JO, Pfeiffer M, Kolen JCA, Davis BAS (2016) Large scale anthropogenic reduction of forest cover in Last Glacial Maximum Europe. PLoS One 11:e0166726. https://doi.org/10.1371/ journal.pone.0166726

Loeppert RH, Suarez DL (1996) Carbonate and gypsum. Publication from USDA-ARS/UNL Faculty

Magny M (1993) Solar influences on Holocene climatic changes illustrated by correlations between past lake-level fluctuations and the atmospheric ${ }^{14} \mathrm{C}$ record. Quaternary Res 40:1-9. https://doi.org/ 10.1006/qres.1993.1050

Magny M (1995) Successive oceanic and solar forcing indicated by Younger Dryas and Early Holocene climatic oscillations in the
Jura. Quaternary Res 43:279-285. https://doi.org/10.1006/qres. 1995.1034

Malnati L (2010) Bologna preromana alla luce degli ultimi scavi. Quaderni di Archeologia dell'Emilia Romagna, 25: 209-222. ISBN: 9788878144163

Malkiewicz M, Waroszewski J, Bojko O, Egli M, Kabala C (2016) Holocene vegetation history and soil development reflected in the lake sediments of the Karkonosze Mountains (Poland). The Holocene 26. https://doi.org/10.1177/0959683615622546

Marchesini M, Marvelli S, Lobietti A (2017) The palynology contribution in palaeoenvironmental investigations. A case-study of a Lateglacial-Holocene sedimentary sequence near Bologna (Northern Italy). EQA - Environ Qual 25: 39-47. https://doi.org/10.6092/ issn.2281-4485/7633

Marcolla A, Miola A, Mozzi P, Monegato G, Asioli A, Pini R, Stefani C (2021) Middle Pleistocene to Holocene palaeoenvironmental evolution of the south-eastern Alpine foreland basin from multiproxy analysis. Quatern Sci Rev 259:106908. https://doi.org/10. 1016/j.quascirev.2021.106908

Martelli L, Santulin M, Sani F, Tamaro A, Bonini M, Rebez A, Corti G, Slejko D (2017a) Seismic hazard of the Northern Apennines based on 3D seismic sources. J Seismol 21:1251-1275. https:// doi.org/10.1007/s10950-017-9665-1

Martelli L, Bonini M, Calabrese L, Corti G, Ercolessi G, Molinari FC, Piccardi L, Pondrelli S, Sani, F, Severi P (2017b). Explanatory notes of the seismotectonic map of the Emilia-Romagna Region and surrounding areas. 93pp

Mauri A, Davis BAS, Collins PM, Kaplan JO (2015) The climate of Europe during the Holocene: a gridded pollen-based reconstruction and its multi-proxy evaluation. Quat Sci Rev 112:109-127. https://doi.org/10.1016/j.quascirev.2015.01.013

Mazier F, Galop D, Brun C, Buttler A (2006) Modern pollen assemblages from grazed vegetation in the western Pyrenees, France: a numerical tool for more precise reconstruction of past cultural landscapes. The Holocene 16:91-103. https://doi.org/10.1191/ 0959683606hl908rp

Meier HA, Driese SG, Nordt LC, Forman SL, Dworkin SI (2014) Interpretation of Late Quaternary climate and landscape variability based upon buried soil macro- and micromorphology, geochemistry, and stable isotopes of soil organic matter, Owl Creek, central Texas, USA. CATENA 114:157-168. https://doi. org/10.1016/j.catena.2013.08.019

Mercuri AM, Bandini Mazzanti M, Florenzano A, Montecchi MC, Rattighieri E, Torri P (2013) Anthropogenic pollen indicators (Api) from archaeological sites as local evidence of humaninduced environments in the Italian peninsula. Annali Di Botanica 3:143-153. https://doi.org/10.4462/annbotrm-10316

Miehe G, Miehe S, Kaiser K, Reudenbach C, Behrendes L, Duo L, Schlütz F (2009) How old is pastoralism in Tibet? An ecological approach to the making of a Tibetan landscape. Palaeogeogr Palaeoclimatol Palaeoecol 276:130-147. https://doi.org/10.1016/j. palaeo.2009.03.005

Miola A (2012) Tools for non-pollen palynomorphs (NPPs) analysis: a list of quaternary NPP types and reference literature in English language (1972-2011). Rev Palaeobot Palynol 186:142-161. https://doi.org/10.1016/j.revpalbo.2012.06.010

Moore PD, Webb A, Collinson ME (1994) Pollen analysis, II ed., Blackwell Sc., Pbl., Oxford ISBN-10: 0865428956

Muttoni G, Carcano C, Garzanti E, Ghielmi M, Piccin A, Pini R, Rogledi S, Sciunnach D (2003) Onset of major Pleistocene glaciations in the Alps. Geology 31:989-992. https://doi.org/10.1130/G19445.1

Natali C, Bianchini G (2015) Thermally based isotopic speciation of carbon in complex matrices: a tool for environmental investigation. Environ Sci Pollut Res 22:12162-12173. https://doi.org/10. 1007/s11356-015-4503-x 
Natali C, Bianchini G, Vittori Antisari L (2018) Thermal separation coupled with elemental and isotopic analysis: a method for soil carbon characterisation. CATENA 164:150-157. https://doi.org/ 10.1016/j.catena.2018.02.022

Natali C, Bianchini G, Carlino P (2020) Thermal stability of soil carbon pools: inferences on soil nature and evolution. Thermochim Acta 683:178478. https://doi.org/10.1016/j.tca.2019.178478

Natali C, Bianchini G, Cremonini S, Salani GM, Vianello G, Brombin V, Ferrari M, Vittori Antisari L (2021) Peat soil burning in the Mezzano Lowland (Po Plain, Italy): triggering mechanisms and environmental consequences. GeoHealth 5, e2021GH000444. https://doi.org/10.1029/2021GH000444

Nilsson SI, Miller HG, Miller GD (1982) Forest growth as a possible cause of soil and water acidification: an examination of the concepts. Oikos 39:40-49. https://doi.org/10.2307/3544529

Obase T, Abe-Ouchi A (2019) Abrupt Bølling-Allerød warming simulated under gradual forcing of the Last Deglaciation. Geophys Res Lett 46:11397-11405. https://doi.org/10.1029/2019GL084675

Pérez-Lambán F, Peña-Monné JL, Badía-Villas D, Picazo JV, Vicente J, Sampietro-Vattuone MM, Alcolea M, Aranbarri J, GonzálezSampériz P, Fanlo J (2017) Holocene environmental variability in the Central Ebro Basin (NE Spain) from geoarchaeological and pedological records. CATENA 163:147-164. https://doi.org/ 10.1016/j.catena.2017.12.017

Pessina A, Tinè V (2008) Archeologia del Neolitico. L'Italia tra VI e IV millennio a.c. Carocci Editore, Urbino: 375 pp. ISBN: 8843045857

Picotti V, Pazzaglia FJ (2008) A new active tectonic model for the construction of the Northern Apennines mountain front near Bologna (Italy). J Geophys Res 113: BO8412. https://doi.org/10.1029/ 2007JB005307

Pignatti S, Guarino R, La Rosa M (2017) Flora d'Italia. $2^{\circ}$ edizione. Edagricole di New Business Media, Bologna. ISBN: 8850652437

Pini R (2002) A high-resolution Late-Glacial-Holocene pollen diagram from Pian di Grembo (Central Alps, Northern Italy)

Piqué R, Revelles J, Berihuete-Azorín M, Lladó JG, Palomo A, Terradas $X$ (2020) Use of fungi for tinder at the Early Neolithic settlement of La Draga (NE Iberia). Quatern Int 541:152-161. https://doi. org/10.1016/j.quaint.2019.12.002

Power MJ (2013) A 21000-year history of fire. In Belcher CM (Ed), Fire phenomena and the earth system: an interdisciplinary guide to fire science, John Wiley \& Sons: 207-227. ISBN: 978-0-470-65748-5

Puppi G, Speranza M, Ubaldi D, Zanotti AL (2010) Le serie di vegetazione della Regione Emilia Romagna. In Blasi C. (Ed.) La vegetazione dell'Emilia Romagna. Palombi e Partners S.r.l.: 181-204. ISBN 978-88-6060209-9

Rasmussen SO, Bigler M, Blockley SP, Blunier T, Buchardt SL, Clausen HB, Cvijanovic I, Dahl-Jensen D, Johnsen SJ, Fischer H, Gkinis V, Guillevic M, Hoek WZ, Lowe JJ, Pedro JB, Popp T, Seierstad IK, Steffensen JP, Svensson AM, Vallelonga P, Vinther BM, Walker MJC, Wheatley JJ, Winstrup M (2014) A stratigraphic framework for abrupt climatic changes during the Last Glacial period based on three synchronized Greenland ice-core records: refining and extending the INTIMATE event stratigraphy. Quat Sci Rev 106:14-28. https://doi.org/10.1016/j. quascirev.2014.09.007

Ravazzi C, Donegana M, Vescovi E, Arpenti E, Caccianiga M, Kaltenrieder P, Londeix L, Marabini S, Mariani S, Pini R, Vai GB, Wick L (2006) A new Late-glacial site with Picea abies in the northern Apennine foothills: an exception to the model of glacial refugia of trees. Veget Hist Archaeobot 15:357-371. https://doi. org/10.1007/s00334-006-0055-9

Ravazzi C, Deaddis M, De Amicis M, Marchetti M, Vezzoli G, Zanchi A (2012) The last 40 ka evolution of the Central Po Plain between the Adda and Serio rivers. Geomorphologie 18: 131-154. https:// doi.org/10.4000/geomorphologie.9794

Reille M (1992) Pollen et spores d'Europe et d'Afrique du Nord, Laboratoire de botanique historique et palinologie, URA CNRS 1152, Marseille

Reille M (1995) Pollen et spores d'Europe et d'Afrique du Nord, Supplement I and II, Laboratoire de botanique historique et palinologie, URA CNRS 1152, Marseille

Reimer PJ, Baillie MGL, Bard E, Bayliss A, Beck JW, Bertrand CJH, Blackwell PG, Buck CE, Burr GS, Cutler KB, Damon PE, Edwards RL, Fairbanks RG, Friedrich M, Guilderson TP, Hogg AG, Hughen KA, Kromer B, McCormac G, Manning S, Bronk Ramsey C, Reimer RW, Remmele S, Southon JR, Stuiver M, Talamo S, Taylor FW, van der Plicht J, Weyhenmeyer CE (2004) INTCAL04 terrestrial radiocarbon age calibration, 0-26 cal kyr bp. Radiocarbon 46:1299-1304. https://doi.org/10.1017/ S0033822200033154

Reimer PJ, Bard E, Bayliss A, Beck JW, Blackwell PG, Bronk Ramsey C, Buck CE, Cheng H, Edwards RL, Friedrich M, Grootes PM, Guilderson TP, Haflidason H, Hajdas I, Hatté C, Heaton TJ, Hogg AG, Hughen KA, Kaiser KF, Kromer B, Manning SW, Niu M, Reimer RW, Richards DA, Scott EM, Southon JR, Turney CSM, van der Plicht J (2013) IntCal13 and Marine13 radiocarbon age calibration curves 0-50,000 years cal BP. Radiocarbon 55:1869-1887. https://doi.org/10.2458/azu_js_rc.55.16947

Reimer PJ, Austin WEN, Bard E, Bayliss A, Blackwell PG, Bronk Ramsey C, Butzin M, Cheng H, Edwards RL, Friedrich M, Grootes PM, Guilderson TP, Hajdas I, Heaton TJ, Hogg AG, Hughen KA, Kromer B, Manning SW, Muscheler R, Palmer JG, Pearson C, van der Plicht J, Reimer RW, Richards DA, Scott EM, Southon JR, Turney CSM, Wacker L, Adolphi F, Büntgen U, Capano M, Fahrni SM, Fogtmann-Schulz A, Friedrich R, Köhler P, Kudsk S, Miyake F, Olsen J, Reinig F, Sakamoto M, Sookdeo A, Talamo S (2020) The IntCal20 Northern Hemisphere radiocarbon age calibration curve (0-55 cal kBP). Radiocarbon 62(4):725-757. https://doi.org/10.1017/RDC.2020.41

Resco de Dios V, Hedo J, Cunill Camprubí À, Thapa P, Martínez del Castillo E, Martínez de Aragón J, Bonet JA, Balaguer-Romano R, Díaz-Sierra R, Yebra M, Boer MM (2021) Climate change induced declines in fuel moisture may turn currently fire-free Pyrenean mountain forests into fire-prone ecosystems. Sci Total Environ 797:149104. https://doi.org/10.1016/j.scitotenv.2021.149104

Robinson M (2014) The ecodynamics of clearance in the British Neolithic. Environ Archaeol 19(3):291-297. https://doi.org/ 10.1179/1749631414Y.0000000028

Rösch M, Ehrmann O, Herrmann L, Schulz E, Bogenrieder A, Goldammer JP, Hall M, Page H, Schier W (2002) An experimental approach to Neolithic shifting cultivation. Veg Hist Archaeobot 11:143-154. https://doi.org/10.1007/s003340200028

Samartin S, Heiri O, Lotter AF, Tinner W (2012) Climate warming and vegetation response after Heinrich event 1 (16 700-16 000 cal yr BP) in Europe south of the Alps. Clim past 8:1913-1927. https://doi.org/10.5194/cp-8-1913-2012

Scapozza C, Castelletti C, Soma L, Dall'Agnolo S, Ambrosi C, (2014) Timing of LGM and deglaciation in the Southern Swiss Alps. Géomorphologie 20:307-322. https://doi.org/10.4000/ geomorphologie. 10753

Schaetzl R, Anderson S (2005) Soils, paleosols and paleoenvironmental reconstruction. In Soils: Genesis and Geomorphology (pp. 619-652). Cambridge: Cambridge University Press. https://doi. org/10.1017/CBO9780511815560.016

Schoeneberger PJ, Wysocki DA, Benham EC (2012) Soil survey staff. In: Field Book for Describing and Sampling Soils. Version 3.0. Natural Resources Conservation Service National Soil Survey Center, Lincoln, NE. ISBN 978-0-16-091542-0 
Serandrei-Barbero R, Bertoldi R, Canali G, Donnici S, Lezziero A (2005) Paleoclimatic record of the past 22,000 years in Venice (Northern Italy): biostratigraphic evidence and chronology. Quat Int 140-141:37-52. https://doi.org/10.1016/j.quaint.2005.05.003

Shakun JD, Carlson AE (2010) A global perspective on Last Glacial Maximum to Holocene climate change. Quat Sci Rev 29:18011816. https://doi.org/10.1016/j.quascirev.2010.03.016

Sofronov M, Volokitina A, Shvidenko A (1998) Wildland fires in the north of Central Siberia. Commonwealth Forestry Rev 77:124-127

Sorensen A (2017) On the relationship between climate and Neandertal fire use during the Last Glacial in south-west France. Quatern Int 436:114-128. https://doi.org/10.1016/j.quaint.2016.10.003

Stuiver M, Polach A (1977) Discussion-reporting of 14C data. Radiocarbon 19:355-363. https://doi.org/10.1017/S0033822200003672

Stuiver M, Reimer P, Braziunas T (1998) High-precision radiocarbon age calibration for terrestrial and marine samples. Radiocarbon 40(3):1127-1151. https://doi.org/10.1017/S0033822200019172

Svensson A, Andersen KK, Bigler M, Clausen HB, Dahl-Jensen D, Davies SM, Johnsen SJ, Muscheler R, Parrenin F, Rasmussen SO, Röthlisberger RR, Seierstad I, Steffensen JP, Vinther BM (2008) A 60000 year Greenland stratigraphic ice core chronology. Clim past 4:47-57. https://doi.org/10.5194/cp-4-47-2008

Tabor NJ, Myers TS (2015) Paleosols as indicators of paleoenvironment and paleoclimate. Annu Rev Earth Planet Sci 43:333-361. https://doi.org/10.1146/annurev-earth-060614-105355

Tallón-Armada R, Costa-Casais M, Schellekens J, Taboada Rodríguez T, Vives-Ferrándiz Sánchez J, Ferrer García C, Abel Schaad D, López-Sáez JA, Carrión Marco Y, Martínez Cortizas A (2014) Holocene environmental change in Eastern Spain reconstructed through the multiproxy study of a pedo-sedimentary sequence from Les Alcusses (Valencia, Spain). J Archaeol Sci 47:22-38. https://doi.org/10.1016/j.jas.2014.03.023

Tolksdorf JF, Turner F, Kaiser K, Eckmeier E, Bittmann F, Veil S (2014) Potential of palaeosols, sediments and archaeological features to reconstruct Late Glacial fire regimes in the northern Central Europe-case study Grabow site and overview. Z Geomorphol 58:211-232. https://doi.org/10.1127/0372-8854/2013/S-00155

Torri P (2011) Storia del paesaggio vegetale e dell'impatto antropico nell'area del Gran Sasso d'Italia (Abruzzo) in base a polline, palinomorfi non pollinici e microcarboni (sondaggi di Piano Locce, $1225 \mathrm{~m} \mathrm{slm}$ ). PhD thesis, Università degli Studi di Ferrara, 187 pp. (https://iris.unife.it/retrieve/handle/11392/2388754/123273/ 402.pdf)

Traverse A (2007) Paleopalynology. II edition. Springer, New York, 814 pp. ISBN 978-1-4020-5610-9

Ulery AL, Graham RC, Amrhein C (1993) Wood-ash composition and soil $\mathrm{pH}$ following intense burning. Soil Sci 156:358-364. https:// doi.org/10.1097/00010694-199311000-00008

Vescovi E, Kaltenrieder P, Tinner W (2010) Late-Glacial and Holocene vegetation history of Pavullo nel Frignano (Northern Apennines, Italy). Rev Palaeobot Palynol 160:32-45. https://doi.org/ 10.1016/j.revpalbo.2010.01.002

Vittori Antisari L, Cremonini S, Desantis P, Vianello G (2011) Anthropedogenic cycles in a chronosequence from the bronze age to renaissance period (Bologna, Italy). EQA 6:1-6. https:// doi.org/10.6092/issn.2281-4485/3824

Vittori Antisari L, Cremonini S, Desantis P, Calastri C, Vianell G (2013a) Chemical analysis of ancient anthro-technosols in a Bronze up to Middle Ages archaeological sequence in Bologna (Italy). J Archaeol Sci 40:3660-3671. https://doi.org/10.1007/ s11368-015-1266-4

Vittori Antisari L, Ventura F, Simoni A, Piana S, Rossi Pisa P, Vianello G (2013b) Assessment of pollutants in wet and dry deposition in a suburban area around a waste to energy plants (WEP) in Northern Italy. J Environ Prot 4:16-25. https://doi.org/10.4236/ jep.2013.45A003

Vittori Antisari L, Bianchini G, Dinelli E, Falsone G, Gardini A, Simoni A, Tassinari R, Vianello G (2014) Critical evaluation of an intercalibration project focused on the definition of new multielement soil reference materials (AMS-MO1 AND AMS-ML1). EQA 15:41-66. https://doi.org/10.6092/issn.2281-4485/4553

Vittori Antisari L, Bianchini G, Cremonini S, Marvelli S, Vianello G (2016) Multidisciplinary study of a Lateglacial-Holocene sedimentary sequence near Bologna (Italy) insights on natural and anthropogenic impacts on the landscape dynamics. J Soil Sediment 16:645-662. https://doi.org/10.1007/s11368-015-1266-4

Vysloužilová B, Ertlen D, Schwartz D, Šefrna L (2016) Chernozem. From concept to classification: a review. AUC Geographica 51:85-95. https://doi.org/10.14712/23361980.2016.8

Walker MJC, Berkelhammer M, Björck S, Cwynar LC, Fisher DA, Long AJ, Lowe JJ, Newnham RM, Rasmusse SO, Weiss H (2012) Formal subdivision of the Holocene Series/Epoch: a Discussion Paper by a Working Group of INTIMATE (Integration of ice-core, marine and terrestrial records) and the Subcommission on Quaternary Stratigraphy (International Commission on Stratigraphy). J Quat Sci 27(7):649-659. https://doi.org/10. 1002/jqs. 2565

Zanchetta G, Bini M, Cremaschi M, Magny M, Sadori L (2013) The transition from natural to anthropogenic-dominated environmental change in Italy and the surrounding regions since the Neolithic: an introduction. Quatern Int 303:1-9. https://doi.org/10. 1016/j.quaint.2013.05.009

Zhao H, Zhang Z, Ying H, Chen J, Zhen S, Wang X, Shan Y (2021) The spatial patterns of climate-fire relationships on the Mongolian Plateau. Agric for MeteorolVolumes 308-309:108549. https://doi.org/10.1016/j.agrformet.2021.108549

Zethof JHT, Leue M, Vogel C, Stoner SH, Kalbitz K (2019) Identifying and quantifying geogenic organic carbon in soils - the case of graphite. Soil 5:383-398. https://doi.org/10.5194/ soil-5-383-2019

Zhou R, Wen X, Lu L, Li Y, Huang C (2021) Holocene paleosols and paleoclimate for the arid upper Minjiang River valley in the eastern Tibetan Plateau. CATENA 206:105555. https://doi.org/ 10.1016/j.catena.2021.105555

Publisher's Note Springer Nature remains neutral with regard to jurisdictional claims in published maps and institutional affiliations. 